CERE Working Paper, 2020:8

\title{
Compliance with the EU Waste Hierarchy: It is a matter of stringency, enforcement ... and time!
}

\author{
Alejandro Egüez
}

The Centre for Environmental and Resource Economics (CERE) is an inter-disciplinary and inter-university research centre at the Umeå Campus: Umeå University and the Swedish University of Agricultural Sciences. The main objectives with the Centre are to tie together research groups at the different departments and universities; provide seminars and workshops within the field of environmental \& resource economics and management; and constitute a platform for a creative and strong research environment within the field.

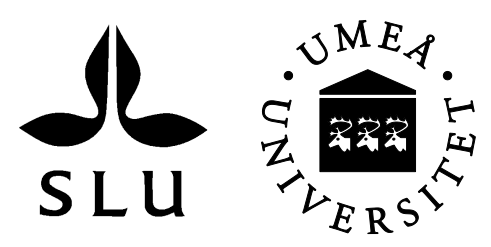




\title{
Compliance with the EU Waste Hierarchy: It is a matter of stringency, enforcement ... and time!
}

\author{
Alejandro Egüez \\ alejandro.eguez@umu.se \\ Centre for Environmental and Resource Economics (CERE) \\ Department of Economics \\ Umeå School of Business, Economics and Statistics (USBE) \\ Umeå University
}

\begin{abstract}
This paper assesses whether and to what extent income and the stringency and enforcement (S\&E) of environmental regulation influence compliance with the EU Waste Hierarchy (EWH), i.e., how EU member states treat waste. The EWH prioritizes waste prevention and re-use over recycling, which is ranked above waste to energy (WtE), while incineration and landfilling are the least preferred options. Biennial panel data for the period 2010-2016 is used to create a compliance index based on the waste treatment alternatives in the EWH. Waste (excluding major mineral waste) of 26 European Union countries is examined. This study is the first of its kind to regress an EWH compliance index on income, stringency and enforcement of environmental regulation, and other variables that are also expected to affect the relative benefits and costs of waste treatment like population density, heating demand, and electricity prices. In conjunction, the shares of landfilling, incineration, WtE, and recycling are also modeled to capture the effect of these variables in the waste treatment mix. Stringency and enforcement of environmental regulation have a positive effect on compliance with the EWH, which has increased over time.
\end{abstract}

Keywords: EU waste hierarchy, waste treatment ladders, income, policy stringency, policy enforcement.

JEL Codes: Q53, 044, R11.

\section{Highlights:}

- A compliance index is created based on the waste treatment ladders of the EU Waste Hierarchy;

- Higher stringency and enforcement of environmental regulation is related to less landfilling;

- Compliance with the EU Waste Hierarchy has increased over time. 


\section{Introduction}

This paper investigates the effect of income and the stringency and enforcement (S\&E) of environmental regulation on how waste is treated and its compliance with the EU Waste Hierarchy (EWH). The EWH is a crucial part of the EU Action Plan for the Circular Economy. It establishes a hierarchy of priorities as to how waste should be treated. According to the EU Waste Framework Directive ${ }^{1}$, countries shall take into consideration the hierarchy illustrated in Appendix A, i.e., the EWH. Waste prevention and re-use are at the top of the hierarchy, followed by material recycling, waste to energy (WtE), with disposal methods like incineration and landfilling given as last resorts. By following this directive, countries design and implement policies to promote a shift towards the upper levels in the hierarchy. ${ }^{2}$

The EWH is a top-down policy guideline that EU member states need to follow in line with the Waste Framework Directive. However, countries differ concerning income levels, stringency and enforcement of environmental regulations, and other aspects, e.g., population density and heating demand. Country-specific characteristics like these likely influence the cost-benefit structure of waste treatment options and, in turn, levels of compliance with the EWH. ${ }^{3}$ The objective of this paper is to estimate if and how these country-specific characteristics affect the waste treatment mix and compliance with the EWH in EU member states. To this end, an EWH compliance index is constructed and regressed on the countries' characteristics. Also, a system of seemingly unrelated regression equations (SURE) is estimated to show if and how the characteristics mentioned above influence the waste treatment mix, captured by the shares of landfilling, incineration, $\mathrm{WtE}$, and recycling. The data used in the analyses are biennial panel data for the period 2010-2016.

\footnotetext{
${ }^{1}$ Directive $2008 / 98 /$ EC on waste.

${ }^{2}$ The focus of this paper is on the ladders of the EWH concerning waste treatment, i.e., landfilling, incineration, $\mathrm{WtE}$, and recycling. Waste prevention and re-use are beyond the scope of this paper. ${ }^{3}$ According to the EU's Directive 2008/98/EC (Article 4: Waste Hierarchy, numeral 4, last paragraph): "Member States shall take into account the general environmental protection principles of precaution and sustainability, technical feasibility and economic viability, protection of resources as well as the overall environmental, human health, economic and social impacts,..." (my emphasis).
} 
The existing literature has looked at the determinants of waste treatment, mainly in the context of substituting landfilling with other waste treatment options like incineration or recycling. ${ }^{4}$ However, compliance with the EWH goes beyond diversion from landfilling because $\mathrm{WtE}$ and recycling are alternative waste treatment methods with different rankings in the EWH. To accommodate this, a composite indicator to explicitly address the question of compliance with the EWH is required.

This paper adds to the literature by constructing a waste hierarchy compliance index. This index is based on different weights assigned to the share of waste that is recycled, recovered as $\mathrm{WtE}$, incinerated, and landfilled. The compliance index is then regressed on specific country-specific characteristics that include GDP per capita, the stringency and enforcement of environmental regulation, population density, heating demand, and electricity prices. By doing so, this paper complements recent attempts to capture compliance with the EWH in an indicator (Castillo-Giménez, Montañés, \& Picazo-Tadeo, 2019; Pires \& Martinho, 2019).

Countries treat waste in different ways because the relative costs between waste treatment alternatives differ. ${ }^{5}$ As Marin et al. (2018) accurately synthesize, the empirical literature highlights the effect of income, environmental policy, and population density in diversion from landfilling in favor of alternative waste treatment methods. Income affects the relative costs of waste treatment options because of its role in technological progress and social preferences towards the environment (Johansson \& Kriström, 2007; Karousakis, 2009). Hereafter, pro-environmental social preferences assume that while the marginal utility of income decreases, the marginal utility of the environment increases. As the marginal utility of the environment increases, society favors stringent and enforceable environmental regulations.

\footnotetext{
${ }^{4}$ See, e.g.: Antonioli, Caratù, \& Nicolli (2018); Ichinose, Yamamoto, \& Yoshida (2011); Karousakis (2009); Marin, Nicolli, \& Zoboli (2018); Mazzanti, Montini, \& Nicolli (2009a, b); Mazzanti \& Zoboli (2008); Nicolli, Mazzanti, \& lafolla (2012).

${ }^{5}$ Tradition, habits, culture, and social norms also play a role, especially in respect of recycling behavior, which affects how waste is treated. See, e.g.: Crociata, Agovino, \& Sacco (2015); Henriksson, Åkesson, \& Ewert (2010); Kirakozian (2016).
} 
Stringency refers to the strictness or tightness of a regulation, e.g., high environmental taxes. Enforcement refers to the mechanisms and institutions in place to comply with the regulations. In the case of environmental taxes, enforcement is related to its collection mechanisms. Both stringency and enforcement have an impact on the effectiveness of a regulation. For example, enforcement mechanisms may be very tough due to the rule of law, but still regulations may be lax, e.g., low environmental taxes. Likewise, high environmental taxes may be stringent, but weak enforcement institutions will affect the overall effectiveness of the policy instrument.

If environmental policy is in line with the Waste Framework Directive, its purpose is to affect the relative prices for waste treatment options and promote the most preferred methods in the $\mathrm{EWH}$, i.e., recycling over $\mathrm{WtE}$, and $\mathrm{WtE}$ over incineration and landfilling. As to population density, it affects the relative costs of waste treatment options because of changes in the opportunity cost of land and the marginal costs of waste separation and collection due to economies of scale (Berglund \& Söderholm, 2003; Berglund, Söderholm, \& Nilsson, 2002; Johnstone \& Labonne, 2004; Nicolli, Mazzanti, \& lafolla, 2012).

As mentioned above, previous empirical studies have mainly focused on what explains diversion from landfill, where there is evidence that income, environmental policy, and population density play a role. However, by not addressing WtE explicitly as a dependent variable, some determinants can be missed. This paper adds to the literature by incorporating heating demand and electricity prices as regressors in the econometric estimations. These variables may affect the competitiveness of WtE. Some WtE plants generate heat for local district heating networks. Therefore, the heating market plays an important role, and heating demand cannot be dismissed. The electricity price also affects WtE in different ways. Some WtE plants are combined heat and power (CHP) plants, where electricity is a byproduct, while others can only supply electricity using, for example, biogas. Higher electricity prices will incentivize the production of electricity. Another reason is that district heating competes with other heating sources, like heat pumps, in a broader heating market. In the case of heat pumps, they require 
electricity to run, and higher electricity prices will, cæteris paribus, reduce the relative price of district heating.

The paper is structured as follows. The theoretical framework is presented in section II. A review of the empirical literature is set out in section III. In section IV, the data and methods are described. Results are reported in section $\mathrm{V}$. The main conclusions and discussion are summarized in section VI.

\section{Theoretical framework}

From an economic perspective, countries choose how to treat their waste, considering the present value of private and social costs and benefits between different alternatives (Rasmussen et al., 2005). Theoretically, this implies an optimal amount of landfilled, incinerated, WtE, and recycled waste. Brisson (1997) proposes a simple theoretical framework to obtain the optimal distribution of recycling, incineration, and landfilling. Under this framework, the policymaker wants to minimize the Net Social Costs (NSC) of waste treatment. Considering the waste treatment methods in the $\mathrm{EWH}$, the optimality condition follows the equi-marginal condition where the marginal net social cost (MNSC) is equal for all the waste treatment alternatives. See equation (1).

$$
M N S C_{\text {Landfill }}=M N S C_{\text {Incineration }}=M N S C_{W t E}=M N S C_{\text {Recycling }}
$$

However, there remains the challenge of deriving benefit and cost functions for each option. A full valuation of the private and social costs and benefits is not always reachable. Instead, one can think that the country characteristics, like the ones evaluated in this paper, will directly or indirectly affect the benefits and costs of treating waste. See equation (2).

$$
N S C\left(W_{i}\right)=\operatorname{Costs}_{i}\left(W_{i}(C C)\right)-\text { Benefits }_{i}\left(W_{i}(C C)\right)
$$

Where $i$ represents each of the waste treatment methods in the EWH and $C C$ is a set of country characteristics that affect the cost and benefits structure of the system, i.e., the 
relative costs. The model above serves as a theoretical basis for this paper because the marginal net social costs of each of the alternatives that define the equi-marginal optimality condition are intrinsically affected by a set of country-specific characteristics, CC. Moreover, since the waste treatment options are substitutes, changes in their relative costs and benefits will also affect compliance with the EWH.

As in Brisson (1997), the equi-marginal principle between waste treatment alternatives is the basis of other theoretical contributions like Highfill \& McAsey (2001), Conrad (1999), Huhtala (1997), Goddard (1995), and Pearce \& Turner (1993). Highfill \& McAsey (2001) model the optimal level of consumption or waste treatment (either recycling or landfilling) in a representative municipality when income is growing. They show that wealthier municipalities are more likely to favor recycling over landfilling because the marginal value of landfilling is higher in less wealthy municipalities, i.e., the marginal cost of landfilling is higher in wealthier municipalities. Conrad (1999) models the role of policy in the relative costs of waste treatment alternatives from a firm's perspective. He compares the impact of taxing virgin materials versus taxing waste disposal in the relative costs of recycling. He demonstrates that taxes on virgin materials are more effective than taxes on waste disposal to promote recycling. The reason for this is that the value of recycled material increases as virgin materials become more expensive with the tax. Lokrantz (2019) uses a computable general equilibrium (CGE) framework to show the effect of taxes and technological shifts in the EWH. Her simulations suggest that taxes that comply with the EWH may reduce waste generation.

The models of Highfill \& McAsey (2001), Conrad (1999), and Lokrantz (2019) demonstrate that country-specific characteristics like income, taxes, and landfill space affect the relative benefits and costs of waste treatment options, and, therefore, their optimal choices. In this paper, income, the stringency and enforcement of environmental regulation, and population density are some of the country characteristics that are expected to affect how to treat waste and compliance with the EWH. 


\section{Review of the empirical literature}

\section{Literature on income and waste treatment}

Waste treatment methods like recycling and WtE require more advanced technology and infrastructure than traditional waste disposal methods like landfilling or incineration in order to be cost-effective. Wealthier countries may be more likely to afford the development of $\mathrm{WtE}$ and recycling infrastructure. Also, the relative value of the environment increases with income due to the decreasing marginal utility of income (Johnstone \& Labonne, 2004; Karousakis, 2009).

Empirical research looking at the relationship between income and waste treatment commonly relates to the Environmental Kuznets Curve (EKC). These studies often find a negative (Karousakis, 2009; Mazzanti, Montini, \& Nicolli, 2009a, 2009b) or inverted U shape relationship with landfilling (Ichinose, Yamamoto, \& Yoshida, 2011; Mazzanti \& Zoboli, 2008; Nicolli et al., 2012). The geographic scope varies between these studies: Mazzanti \& Zoboli (2008) and Nicolli et al. (2012) use EU data; Karousakis (2009) uses OECD data; Ichinose et al. (2011) use municipal-level data for Japan; and Mazzanti et al. (2009a, b) use provincial-level data for Italy.

Concerning the relationship between income and incineration, Huhtala (1999) find a positive relationship, and Mazzanti \& Zoboli (2008) find a U shape relationship. Marin et al. (2018) find no statistically significant relationships between income and waste treatment in the EU; however, recycling and incineration patents explain changes in the share of recycling and incineration (including WtE). In Marin et al. (2018), income and technological progress captured by the patents variables may be correlated.

The existing literature shows that the relationship between income and recycling can be positive or negative. Technological progress and pro-environmental preferences, due to the decreasing marginal utility of income, may explain a positive relationship between income and recycling. However, recycling may be more labor-intensive than other waste treatment methods, and countries with higher incomes have higher labor costs 
(Berglund \& Söderholm, 2003; Berglund et al., 2002). Also, from the household perspective, as income increases, the opportunity cost of the time and effort needed for recycling increases too (Huhtala, 1999). The net effect of the relationship between income and recycling remains an empirical question, as noted by Berglund \& Söderholm (2003) and Berglund et al. (2002). Huhtala (1999) finds a negative relationship between income and recycling in Finnish households, while Karousakis (2009) finds a positive relationship concerning municipal solid waste (MSW) in OECD countries. Berglund \& Söderholm (2003) and Berglund et al. (2002) show a positive relationship for paper recovery in more than 80 countries worldwide.

Literature on the stringency and enforcement of environmental policy in waste treatment

Waste policies are required to increase compliance with the EWH because they affect the relative costs and benefits of waste treatment to promote some options over others. EU membership entails the implementation of directives into national legislation. Therefore, it is reasonable to assume that environmental policies are in line with the EWH in the Waste Framework Directive. Countries are free to choose different policy instruments to affect the marginal costs of waste treatment, so that recycling becomes cheaper than $\mathrm{WtE}$, and $\mathrm{WtE}$ becomes cheaper than incineration and landfilling. Examples of these policies are: landfill and incineration taxes (or regulatory bans); technology standards that directly increase the marginal cost of landfilling or incinerating; disposal fees, or curbside recycling programs that reduce the relative costs of sorting waste; or capital grants for WtE and recycling infrastructure (Kinnaman, 2009; Werner, 2017).

While data on income and population density is generally comparable between countries and available from official statistics, studies differ in terms of how they model environmental policy. Local studies like Antonioli et al. (2018) and Mazzanti et al. (2009a, b) in Italy, Ichinose et al. (2011) in Japan, or Dijkgraaf \& Gradus (2017) in the Netherlands account for local instruments like landfill taxes, waste tariffs, or sorting systems. Conversely, studies analyzing many countries, like Marin et al. (2018), Mazzanti 
\& Zoboli (2008) and Nicolli et al. (2012) in the EU, and Karousakis (2009) in OECD countries, use environmental policy indexes to reflect the implementation of environmental policy. The policy indexes used in many studies with data from EU members use weights based on the countries' level of implementation or impact of the policies compiled by the European Environment Information and Observation Network (EIONET). Similarly, Karousakis (2009), in the case of OECD countries, used the European Environment Agency's waste legislation and policy index, which assigns different scores based on the level of implementation of different instruments.

Results of these studies confirm a negative relationship between environmental policy and landfilling (Antonioli et al., 2018; Ichinose et al., 2011; Karousakis, 2009; Mazzanti et al., 2009a, 2009b; ${ }^{6}$ Mazzanti \& Zoboli, 2008; Nicolli et al., 2012), and a positive relationship with alternative waste treatment methods (Antonioli et al., 2018; Dijkgraaf \& Gradus, 2017; Marin et al., 2018; Mazzanti \& Zoboli, 2008). Karousakis (2009) is an exception where environmental policy showed a negative relationship with recycling in OECD countries. The author argues that this unexpected result may be due to the timeinvariant nature of the environmental policy index used to measure policy enforcement.

The stringency and enforcement of environmental policies and regulations are a result of social preferences towards the environment. Therefore, the S\&E indicator used in this paper reflects these preferences and not the effect of the implementation of specific waste policies as has been intended in the previous literature.

\section{Literature on population density and waste treatment}

If the amount of land is scarce, and population density is high, the opportunity cost of landfilling is high, so alternative waste treatment methods become more competitive. In contrast, if the land is abundant and population density is low, waste disposal becomes cheaper because of higher transportation and logistical costs of collecting

\footnotetext{
${ }^{6}$ In this case, waste management tariffs are a more effective policy driver for landfill diversion compared with landfill taxes, which do not show a statistically significant relationship, probably due to its low level of enforcement (Mazzanti et al., 2009a, 2009b).
} 
waste for WtE or recycling. However, it is important to note that waste disposal can be either landfilling or incineration without energy recovery. Therefore, even though higher population density in urbanized areas may help to reduce the costs of collection and sorting for recycling, these benefits need to offset the net costs of incineration, which already tackles the space competition issue of landfills. Another aspect to take into consideration is that incineration may cause local pollution and discomfort in highly populated areas. However, technological solutions like tall flue-gas stacks may address this inconvenience.

Previous empirical evidence confirms a negative relationship between population density and landfilling (Antonioli et al., 2018; Ichinose et al., 2011; Karousakis, 2009; Mazzanti et al., 2009a, 2009b; Mazzanti \& Zoboli, 2008; Nicolli et al., 2012) and a positive relationship with incineration (Antonioli et al., 2018; Mazzanti \& Zoboli, 2008). Concerning the relationship with recycling, Mazzanti \& Zoboli (2008) find a negative relationship, mainly driven by a substitution effect from incineration, where a positive relationship was confirmed. Berglund \& Söderholm (2003), Berglund et al. (2002), and Karousakis (2009) show a positive relationship between population density and recycling, probably driven by reduced costs of collection and sorting for recycling in countries with higher population density. The study by Antonioli et al. (2018) did not find a statistically significant relationship between population density and recycling, but the relationships with landfilling and incineration were significant, as stated before. Marin et al. (2018) did not find a statistically significant relationship between population density and any of the analyzed waste treatment methods. The authors argue that this result may be driven by the fact that population density may play a role in waste generation, but not in treatment choices. However, as noted above, there is evidence of the effect of population density in other studies that analyze waste treatment.

Considering the arguments rehearsed in this and the previous section, Table 1 collates some initial presumptions about the relationships between country characteristics (independent variables) and compliance with the EWH and its waste treatment ladders (dependent variables). 
Table 1: Summary of hypotheses

\begin{tabular}{l|c:cccc}
$\begin{array}{c}\text { Dependent Variables } \\
\text { Independent Variables }\end{array}$ & $\begin{array}{c}\text { Compliance } \\
\text { Index }\end{array}$ & $\begin{array}{c}\text { Share of } \\
\text { Landfilling }\end{array}$ & $\begin{array}{c}\text { Share of } \\
\text { Incineration }\end{array}$ & $\begin{array}{c}\text { Share of } \\
\text { WtE }\end{array}$ & $\begin{array}{c}\text { Share of } \\
\text { Recycling }\end{array}$ \\
\hline GDP per capita & & & & & \\
Environmental regulation (S\&E) & + & $(-$ & & $+)$ & \pm \\
Population density & + & $(-$ & & $+)$ \\
Heating degree days & \pm & $(-$ & $+)$ & \pm \\
Electricity price & \pm & & & + & \\
\hline
\end{tabular}

\section{Data and methods}

This paper relies on data from Eurostat and the World Economic Forum (WEF). The analyzed country characteristics and waste treatment data is obtained from Eurostat's open-access databases. The environmental regulation stringency and enforcement indicators are obtained from the WEF. The dataset is a balanced panel for $26 \mathrm{EU}$ member states $^{7}$ with biennial observations for the period 2010-2016. This timeframe is convenient since the Waste Framework Directive dates back to 2008.

The waste category in this study is classified as non-hazardous and includes total waste (excluding major mineral waste). ${ }^{8}$ Excluding major mineral waste increases the degree of comparability between countries. ${ }^{9}$ There is heterogeneity with regard to how countries with different characteristics treat waste. For example, countries like the Netherlands, Denmark, Belgium or Sweden landfill less than $10 \%$ of their total waste, while more than $60 \%$ is landfilled in countries like Romania, Cyprus, Bulgaria, and Greece. The frontrunners in WtE are Finland, Sweden, and Denmark, where nearly half of their waste is recovered into energy. At the same time, less than $5 \%$ is WtE in Cyprus, the UK, Italy, Bulgaria, Croatia, or Greece. See Figure 1.

\footnotetext{
${ }^{7}$ Luxembourg and Malta were excluded from the EU28 dataset, given their outlier characteristics. EU28 countries include Austria, Belgium, Bulgaria, Croatia, Cyprus, Czech Republic, Denmark, Estonia, Finland, France, Germany, Greece, Hungary, Ireland, Italy, Latvia, Lithuania, Luxembourg, Malta, Netherlands, Poland, Portugal, Romania, Slovakia, Slovenia, Spain, Sweden, and United Kingdom.

${ }^{8}$ In the remainder of this paper, total waste refers to total waste (excluding major mineral waste) unless stated otherwise. For further detail on the classification and definition of this waste category and its treatment, see chapter 2 in Eurostat (2013).

${ }^{9}$ See https://ec.europa.eu/eurostat/web/waste/key-waste-streams/waste-excluding-mineral
} 
Figure 1: Treatment of total waste by country (2010-2016)

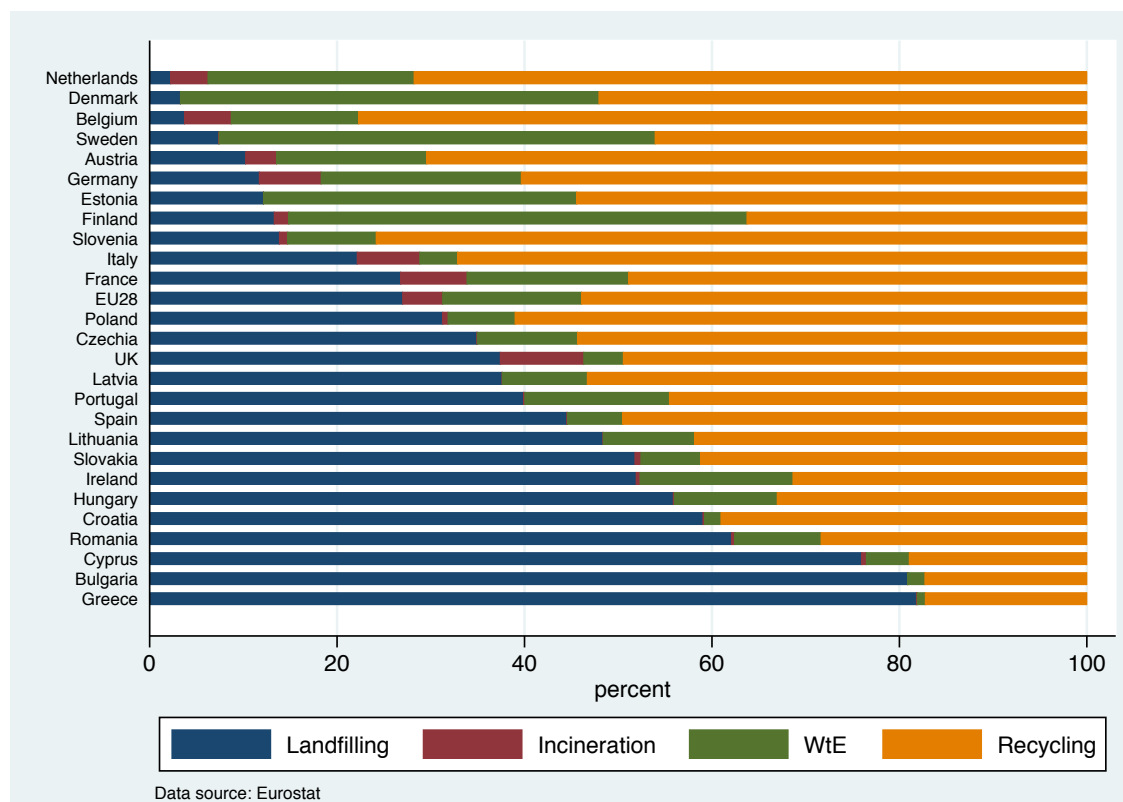

One of the key features of this paper is the construction of a waste hierarchy compliance index ${ }^{10}$ based on the shares of landfilling, incineration, WtE, recycling, and specific weighting coefficients to reflect the hierarchies in the EWH. See equation (3).

$$
C I=W_{D}(L+I)+W_{E}(E)+W_{R}(R)
$$

Where:

$\mathrm{Cl}=$ Compliance index

$L=$ Landfilled waste (tons) / Total treated waste (tons)

$I=$ Incinerated waste (tons) / Total treated waste (tons)

$E=\mathrm{WtE}$ (tons) / Total treated waste (tons)

$R=$ Recycled waste (tons) / Total treated waste (tons)

$W_{D}=$ Weighting coefficient for waste disposal

$W_{E}=$ Weighting coefficient for WtE

$W_{R}=$ Weighting coefficient for recycling

\footnotetext{
${ }^{10}$ For the sake of simplicity, the waste generation component is omitted in the construction of this index, which is limited to the waste treatment alternatives of landfilling, incineration, WtE, and recycling, which are substitutable.
} 
An underlying assumption is that all waste is treated in one of the four alternative ways. Therefore, total treated waste is the sum of landfilling, incineration, $\mathrm{WtE}$, and recycling. The weighting coefficients are exogenously assigned based on the hierarchical order of the waste hierarchy, and different scenarios are considered in a sensitivity analysis. First, landfilling and incineration are considered disposal operations with $W_{D}=1$, followed by WtE with $W_{E}=2$ and recycling with $W_{R}=3$. In this baseline scenario, the maximum possible value of $\mathrm{Cl}$ is 3 in the case that $100 \%$ of the waste is recycled. However, this scenario undertakes a linear reward $(\Delta=1)$ between disposal, WtE, and recycling. Nonlinear scenarios include:

- Pro-recycling scenario, where material recycling is rewarded with a higher relative weight, keeping the same weights for waste disposal and WtE as in the baseline scenario. In this scenario, $W_{D}=1 ; W_{E}=2 ; W_{R}=4$.

- Anti-landfill scenario, where landfilling is punished disproportionally compared to WtE and recycling. In this scenario, $W_{D}=1 ; W_{E}=3 ; W_{R}=4$.

- Combined exponential scenario, where the relative weights for landfilling and WtE are the same as in the previous anti-landfill scenario, but recycling is rewarded more than proportionally. In this scenario, $W_{D}=1 ; W_{E}=3 ; W_{R}=6$.

Figure 2: Waste hierarchy compliance index $(\mathrm{Cl})$ by country

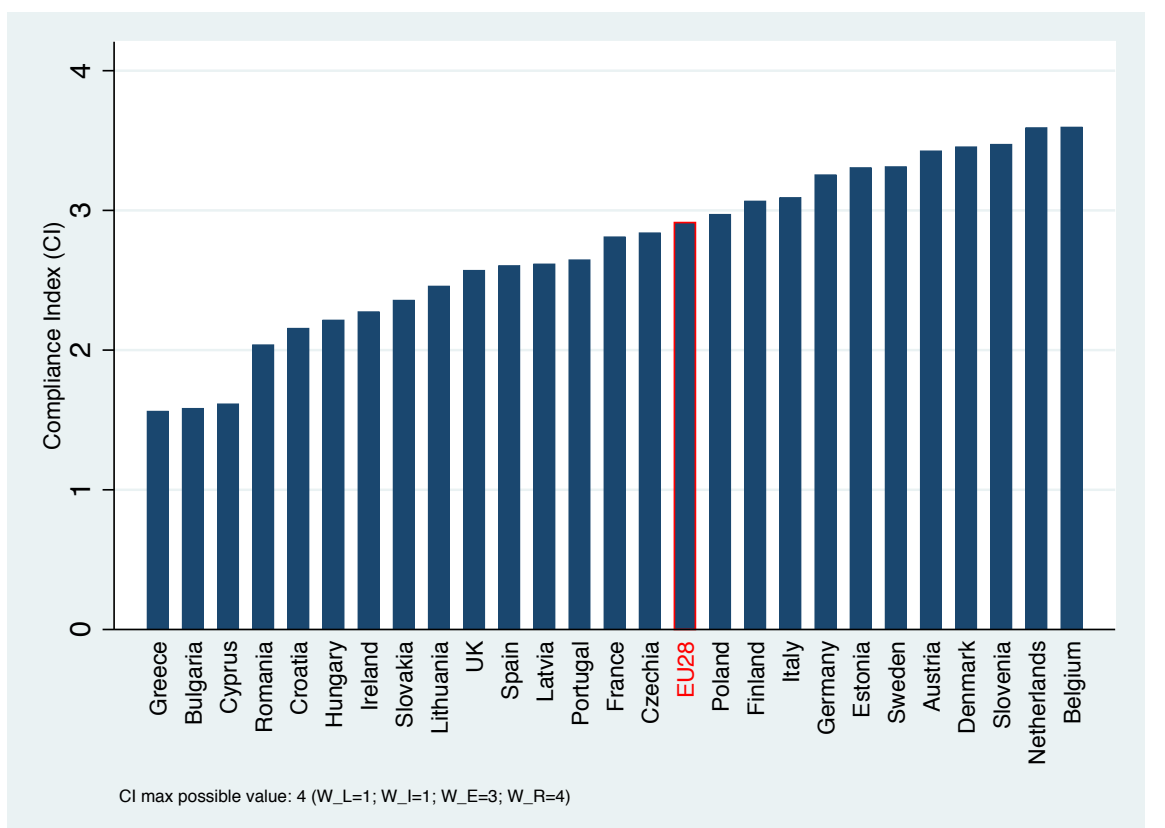


Figure 2 shows a comparison of the countries' compliance index for the anti-landfill scenario. Belgium and the Netherlands are the frontrunners with the highest $\mathrm{Cl}$, while Greece, Bulgaria, and Cyprus have the lowest $\mathrm{Cl}$.

Pires \& Martinho (2019) propose a waste hierarchy index similar to the one proposed in this paper but with different weighting coefficients for the waste treatment alternatives. They use a weighting coefficient of 1 for waste treatment options that contribute to the circularity of materials, and -1 for alternatives against the circular economy. This index aims to capture circularity. However, as the authors state, "the energy recovered by incineration can only be used once, which limits the circularity of materials in the economy." Therefore, computing this index requires either knowledge of which fraction of $\mathrm{WtE}$ contributes to the circular economy or assumptions about these fractions. Alternatively, they propose a streamlined index where recycling has a weighting coefficient of 1 and incineration and landfilling, -1 . The downside of this version of the index in the context of the EWH is that it weights WtE in the same way as waste disposal (incineration and landfilling). However, WtE has a higher priority, listed between recycling and waste disposal in the EWH.

Castillo-Giménez et al. (2019) use another index. They use data envelopment and multicriteria analysis to assign weights to different waste treatment options and generate a composite performance index. Results show that the best performers are Denmark, Austria, and Germany, and the worst performers are most of the Eastern European countries. However, this performance index does not necessarily reflect compliance with the EWH, although they may be correlated. One reason can be that the weights are endogenously determined by how much waste per capita a country treats in a certain way, compared to other countries. The resulting weights used by Castillo-Giménez et al. (2019) to build their performance index are landfill (0.048), incineration including WtE (0.407), recycling (0.103), and composting and digestion (0.442). In this case, material recycling has a lower weight than incineration, while in the EWH, recycling has a higher priority. Moreover, incineration with and without energy recovery receives the same weight, while in the $\mathrm{EWH}$, incineration without energy recovery has the lowest priority as landfilling. 
Besides waste treatment and compliance, there is also heterogeneity in the analyzed country characteristics. Table 2 shows the descriptive statistics of the dependent and independent variables. The variation between countries is higher than the variation within countries (over time). For example, GDP per capita can be nearly four times lower in Eastern European countries like Poland, Hungary, Croatia, and Latvia, compared to Sweden and Denmark. The environmental regulation S\&E indicator has values from below 8 (out of 14) in countries like Bulgaria, Croatia, Greece, Hungary, Italy or Romania, up to above 12 in countries like Austria, Denmark, Finland, Germany, the Netherlands, and Sweden. Population density also differs. The Netherlands and Belgium are at the top of the list and can be more than 20 times denser than countries like Finland and Sweden. Heating degree days (HDD) in some years can be as low as 500 in Cyprus or above 5,000 in Finland and Sweden. Electricity prices can be up to 3 times cheaper in Eastern European countries compared to Germany and Denmark.

Concerning the independent variables, GDP per capita in 2010 thousand EUR ${ }^{11}$ represents income. Population density is the average population per $\mathrm{km}^{2} .{ }^{12}$ Heating degree days (HDD) is a measure of heating requirement. It is calculated according to the following condition: if $T_{M} \leq 15^{\circ} \mathrm{C}$, then $\left[H D D=\sum_{i}\left(18^{\circ} \mathrm{C}-T_{M}^{i}\right)\right]$; else $[H D D=0]$. Where $T_{M}^{i}$ is the mean air temperature of day $i{ }^{13}$ The electricity price is the average price (cent.EUR/kWh) for household consumption between 2,500 and 5,000 kWh per year. ${ }^{14}$ This indicator excludes all taxes and levies because it aims to capture the net value that the energy companies receive to make decisions concerning $\mathrm{WtE}$.

\footnotetext{
${ }^{11}$ Eurostat uses chain-linked volumes. See https://ec.europa.eu/eurostat/cache/metadata/en/nama10_esms.htm

${ }^{12}$ See https://ec.europa.eu/eurostat/cache/metadata/en/demo_r_gind3_esms.htm

${ }^{13}$ See https://ec.europa.eu/eurostat/cache/metadata/en/nrg_chdd_esms.htm

${ }^{14}$ See https://ec.europa.eu/eurostat/cache/metadata/en/nrg_pc_204_esms.htm
} 
Table 2: Descriptive statistics

\begin{tabular}{|c|c|c|c|c|c|c|}
\hline VARIABLES & & Mean & SD & Min & Max & Observati \\
\hline \multicolumn{7}{|l|}{ Independent variables } \\
\hline \multirow{3}{*}{$\begin{array}{l}\text { GDP per capita } \\
(2010 \text { EUR } \times 1000)\end{array}$} & Overall & 22.90 & 12.23 & 5.10 & 53.10 & $N=104$ \\
\hline & Between & & 12.32 & 5.48 & 44.80 & $n=26$ \\
\hline & Within & & 1.48 & 17.43 & 33.73 & $\mathrm{~T}=4$ \\
\hline \multirow{3}{*}{$\begin{array}{l}\text { Environmental regulation } \\
\text { stringency }\end{array}$} & Overall & 5.08 & 0.83 & 2.98 & 6.62 & $N=104$ \\
\hline & Between & & 0.82 & 3.35 & 6.30 & $n=26$ \\
\hline & Within & & 0.18 & 4.54 & 5.56 & $\mathrm{~T}=4$ \\
\hline \multirow{3}{*}{$\begin{array}{l}\text { Environmental regulation } \\
\text { enforcement }\end{array}$} & Overall & 4.70 & 0.97 & 2.81 & 6.38 & $N=104$ \\
\hline & Between & & 0.97 & 3.15 & 6.22 & $n=26$ \\
\hline & Within & & 0.19 & 4.31 & 5.17 & $\mathrm{~T}=4$ \\
\hline \multirow{3}{*}{$\begin{array}{l}\text { Environmental regulation } \\
\text { (S\&E) }\end{array}$} & Overall & 9.78 & 1.78 & 5.79 & 13.01 & $N=104$ \\
\hline & Between & & 1.77 & 6.50 & 12.47 & $n=26$ \\
\hline & Within & & 0.35 & 9.07 & 10.73 & $\mathrm{~T}=4$ \\
\hline \multirow{3}{*}{$\begin{array}{l}\text { Population density } \\
\text { (persons } / \mathrm{km}^{2} \text { ) }\end{array}$} & Overall & 127 & 107 & 18 & 501 & $N=104$ \\
\hline & Between & & 109 & 18 & 497 & $n=26$ \\
\hline & Within & & 2 & 119 & 134 & $\mathrm{~T}=4$ \\
\hline \multirow[t]{3}{*}{ Heating degree days } & Overall & 2987 & 1170 & 496 & 6191 & $N=104$ \\
\hline & Between & & 1154 & 629 & 5657 & $n=26$ \\
\hline & Within & & 273 & 2493 & 3621 & $\mathrm{~T}=4$ \\
\hline \multirow{3}{*}{$\begin{array}{l}\text { Electricity price } \\
\text { (cent.EUR/kWh) }\end{array}$} & Overall & 12.37 & 3.27 & 6.92 & 24.14 & $N=104$ \\
\hline & Between & & 3.06 & 7.54 & 18.87 & $n=26$ \\
\hline & Within & & 1.25 & 6.96 & 18.25 & $\mathrm{~T}=4$ \\
\hline \multicolumn{7}{|l|}{ Dependent variables } \\
\hline \multirow{3}{*}{$\begin{array}{l}\text { Compliance index } \\
\left(W_{D}=1 ; W_{E}=2 ; W_{R}=3\right)\end{array}$} & Overall & 2.10 & 0.41 & 1.21 & 2.81 & $N=104$ \\
\hline & Between & & 0.39 & 1.37 & 2.68 & $n=26$ \\
\hline & Within & & 0.14 & 1.44 & 2.55 & $\mathrm{~T}=4$ \\
\hline \multirow{3}{*}{$\begin{array}{l}\text { Compliance index } \\
\left(W_{D}=1 ; W_{E}=2 ; W_{R}=4\right)\end{array}$} & Overall & 2.58 & 0.59 & 1.31 & 3.68 & $N=104$ \\
\hline & Between & & 0.56 & 1.55 & 3.46 & $n=26$ \\
\hline & Within & & 0.21 & 1.59 & 3.26 & $\mathrm{~T}=4$ \\
\hline \multirow{3}{*}{$\begin{array}{l}\text { Compliance index } \\
\left(W_{D}=1 ; W_{E}=3 ; W_{R}=4\right)\end{array}$} & Overall & 2.73 & 0.65 & 1.33 & 3.75 & $N=104$ \\
\hline & Between & & 0.63 & 1.56 & 3.60 & $n=26$ \\
\hline & Within & & 0.21 & 1.73 & 3.40 & $\mathrm{~T}=4$ \\
\hline \multirow{3}{*}{$\begin{array}{l}\text { Compliance index } \\
\left(W_{D}=1 ; W_{E}=3 ; W_{R}=6\right)\end{array}$} & Overall & 3.68 & 1.00 & 1.53 & 5.47 & $N=104$ \\
\hline & Between & & 0.95 & 1.92 & 5.14 & $n=26$ \\
\hline & Within & & 0.35 & 2.03 & 4.82 & $\mathrm{~T}=4$ \\
\hline \multirow{3}{*}{$\begin{array}{l}\text { Landfilling / Total treatment } \\
\text { (\% share) }\end{array}$} & Overall & 35.62 & 25.45 & 1.47 & 88.56 & $N=104$ \\
\hline & Between & & 24.76 & 2.25 & 80.85 & $n=26$ \\
\hline & Within & & 7.25 & 13.10 & 69.29 & $\mathrm{~T}=4$ \\
\hline \multirow{3}{*}{$\begin{array}{l}\text { Incineration / Total treatment } \\
\text { (\% share) }\end{array}$} & Overall & 1.83 & 3.21 & 0 & 14.87 & $N=104$ \\
\hline & Between & & 2.74 & 0 & 8.95 & $n=26$ \\
\hline & Within & & 1.74 & -4.38 & 12.94 & $\mathrm{~T}=4$ \\
\hline \multirow{2}{*}{$\begin{array}{l}\text { WtE / Total treatment } \\
\text { (\% share) }\end{array}$} & Overall & 15.06 & 14.40 & 0 & 56.12 & $N=104$ \\
\hline & Between & & 13.81 & 1.01 & 49.06 & $n=26$ \\
\hline
\end{tabular}




\begin{tabular}{lllllll}
\hline VARIABLES & & Mean & SD & Min & Max & Observations \\
\hline & Within & & 4.69 & -4.67 & 30.11 & $\mathrm{~T}=4$ \\
Recycling / Total treatment & Overall & 47.49 & 18.54 & 9.75 & 89.18 & $\mathrm{~N}=104$ \\
(\% share) & Between & & 17.33 & 17.27 & 77.37 & $\mathrm{n}=26$ \\
& Within & & 7.22 & 15.17 & 71.04 & $\mathrm{~T}=4$ \\
\hline
\end{tabular}

The environmental regulation's stringency and enforcement indicator is based on two questions in the World Economic Forum's Executive Opinion Survey for the Global Competitiveness Report. The questions to business executives ${ }^{15}$ are: "In your country, how do you assess the stringency of environmental regulations? [1 = Very lax - among the worst in the world; 7 = Among the world's most rigorous]". An equivalent question concerns the enforcement of environmental regulations. The scores and sample sizes by country are reported in Appendix B. For each question, they are calculated as the weighted moving average of the sample for each country. ${ }^{16}$ Table 2 shows that, on average, the assessment of stringency is higher than enforcement. As noted before, stringency and enforcement, together, affect the effectiveness of environmental regulations. The S\&E indicator used in this paper is built upon adding up the scores of the two questions to capture both stringency and enforcement. ${ }^{17}$ It is important to note that this indicator reflects the S\&E of environmental regulations in general and is not specific to waste management. This indicator captures social preferences towards the environment because the S\&E of environmental regulations is a result of how society values the environment.

The use of environmental policy indexes that aim to capture its stringency or enforcement is not free from criticism, especially due to multidimensionality (Brunel \& Levinson, 2016). In the case of waste, multidimensionality is a challenge because each policy has different targets, and policies will affect all waste treatment options because

\footnotetext{
${ }^{15}$ Business executive levels in the survey are, e.g., top executive/owner, senior executive/board management, head of a business unit/head of a region, middle management and advisers, and functional staff.

${ }^{16}$ See https://reports.weforum.org/global-competitiveness-report-2018/appendix-b-the-executiveopinion-survey-the-voice-of-the-business-community/

${ }^{17}$ The Pearson correlation coefficient between the stringency and enforcement scores is 0.9557. Multicollinearity may arise if interaction variables are used. Therefore, adding up the stringency and enforcement scores into a single S\&E indicator is a better option compared to using interaction variables.
} 
they are substitutes. Moreover, a comparison between countries may not be accurate because the design of each policy instrument may differ between locations. For example, landfill taxes and recycling subsidies may have similar aims to increase compliance with the EWH, but they will have different effects in a country's waste treatment mix. Aggregated indicators that are intended to reflect the stringency and enforcement of environmental policy cannot capture the multidimensional characteristics of waste policy. Another challenge is potential collinearity if the stringency or enforcement of environmental policy is highly correlated with other explanatory variables like income.

Sauter (2014) presents an overview of environmental policy enforcement indicators, including survey, monetary, policy-specific, and performance indicators. Monetary and policy-specific indicators like landfill taxes, waste tariffs, or sorting systems can be seen in country-specific studies (Antonioli et al., 2018; Dijkgraaf \& Gradus, 2017; Ichinose et al., 2011; Mazzanti et al., 2009a, 2009b). These may be suitable for single country studies, but in the case of studies analyzing different countries, policies may not be comparable. Performance indicators can be the share of landfilling and other waste treatment methods. However, as noted in the literature reviewed in section III, these have been assessed mostly as dependent variables of landfill diversion and not as policy regressors. This paper uses a survey-based indicator from the WEF that reflects the perceptions of the respondents concerning the stringency and enforcement of environmental regulations. A downside of these types of surveys is that they rely on perceptions. Nevertheless, the WEF's survey is designed with large samples to reflect the structure of each country's economy. ${ }^{18}$

\section{Econometric design}

This paper hypothesizes that the differences in country characteristics explain why they treat their waste differently, and therefore exhibit different degrees of compliance with the EWH (see Table 1). In this context, the econometric design consists of two different

\footnotetext{
${ }^{18}$ See http://www3.weforum.org/docs/GCR2018/04Backmatter/2.\%20Appendix\%20B.pdf
} 
estimations. In the first, the compliance index is regressed on the country characteristics described above, and time-specific effects. In the second group of estimations, instead of the compliance index, the dependent variables are the shares of landfilling, incineration, $\mathrm{WtE}$, and recycling. These shares are regressed on the same country characteristics as before but as a system of equations. Both estimations are analyzed in conjunction, since compliance is a result of the waste treatment mix.

Equation (4) represents the first estimation:

$$
C I_{i t}=\beta_{0}+\beta_{1} Y_{i t}+\beta_{2} R E G_{i t}+\beta_{3} P D_{i t}+\beta_{4} H D D_{i t}+\beta_{5} E L_{i t}+\gamma D Y e a r_{t}+u_{i}+\varepsilon_{i t}
$$

Where $C I$ is the compliance index, $i$ is the country, $t$ is the year, $\beta_{0}$ is the constant term, $Y$ is GDP per capita, $R E G$ is the environmental regulation S\&E indicator, $P D$ is population density, $H D D$ are heating degree days, $E L$ is the electricity price, $D Y e a r$ is a dummy for each observed year with a vector of coefficients $\gamma, u_{i}$ is the time-invariant country effect, and $\varepsilon_{i t}$ is the error term. In the case of random effects, there is no $u_{i}$, and the error term is composed of between- and within-country error terms.

The system of equations in Eq. (5) - (8) contains the shares of landfilling, incineration, $\mathrm{WtE}$, and recycling as dependent variables. Since these waste treatment options are substitutes, it is reasonable to assume that the error terms are correlated across the equations. ${ }^{19}$ Therefore, a multiple equation approach is used to fit Zellner's seemingly unrelated regression models.

$$
\begin{aligned}
& L_{i t}=\alpha_{0}+\alpha_{1}(Y)_{i t}+\alpha_{2}(R E G)_{i t}+\alpha_{3}(P D)_{i t}+\alpha_{4}(H D D)_{i t}+\alpha_{5}(E L)_{i t}+\gamma_{L}(D . Y e a r)_{t}+u_{i}+\varepsilon_{i t} \\
& I_{i t}=\beta_{0}+\beta_{1}(Y)_{i t}+\beta_{2}(R E G)_{i t}+\beta_{3}(P D)_{i t}+\beta_{4}(H D D)_{i t}+\beta_{5}(E L)_{i t}+\gamma_{I}(D . Y e a r)_{t}+u_{i}+\varepsilon_{i t} \\
& E_{i t}=\theta_{0}+\theta_{1}(Y)_{i t}+\theta_{2}(R E G)_{i t}+\theta_{3}(P D)_{i t}+\theta_{4}(H D D)_{i t}+\theta_{5}(E L)_{i t}+\gamma_{E}(D . Y e a r)_{t}+u_{i}+\varepsilon_{i t} \\
& R_{i t}=\lambda_{0}+\lambda_{1}(Y)_{i t}+\lambda_{2}(R E G)_{i t}+\lambda_{3}(P D)_{i t}+\lambda_{4}(H D D)_{i t}+\lambda_{5}(E L)_{i t}+\gamma_{R}(D . Y e a r)_{t}+u_{i}+\varepsilon_{i t}
\end{aligned}
$$

Where $L, I, E$ and $R$ are the shares of landfilling, incineration, $\mathrm{WtE}$, and recycling over total treated waste, respectively. In the case that the system is estimated as a pooled

\footnotetext{
${ }^{19}$ The SURE estimations are supported by Breusch-Pagan tests of independence.
} 
SURE, there is no $u_{i}$. An underlying assumption is that all waste is treated in one of the four alternatives. Therefore, $L_{i t}+I_{i t}+E_{i t}+R_{i t}=1$. To fulfill the rank condition, the estimation procedure of the SURE involves two steps. First, one equation is left out of the estimation. Then, the system is estimated again, including the equation that was previously left out, but now any other equation is left out.

The SURE estimation is reduced to ordinary least squares (OLS) if all equations use the same regressors and values, as in this case (Cameron \& Trivedi, 2010). The latter means that the coefficients of running these equations independently or as a system are the same. However, standard errors may differ. Bootstrapped standard errors are computed for the SURE estimations. ${ }^{20}$ Bootstrapping is a flexible way to estimate robust standard errors because it allows the errors to be heteroskedastic, and if they are homoskedastic, the outcome is not affected (Cameron \& Trivedi, 2010).

Including country fixed effects allows controlling for the unobserved country-specific effects that may explain waste treatment mix and compliance. Therefore, country fixed effects estimations are useful to reveal the context-specific nature of waste management, especially since countries are free to choose which policy instruments they use to comply with the EWH. However, including country-specific effects is not useful to analyze the effect of time-invariant variables (Petersen, 2012). Table 2 shows that the between-variation is higher than the within-variation in all the variables of interest. Therefore, random effects may be helpful in highlighting the differences between countries. In the case of SURE with panel data, fixed effects estimations are equivalent to independent OLS estimations but including country dummies. ${ }^{21}$ The estimation with random effects is not based on OLS and could be more challenging. ${ }^{22}$ An alternative is a pooled SURE estimation but without country dummies. ${ }^{23}$

\footnotetext{
${ }^{20}$ Bootstrapped standard errors are computed using 400 repetitions, as suggested by Cameron \& Trivedi (2010).

${ }^{21}$ Note that this only applies if all equations use the same regressors and values.

${ }^{22}$ XTSUR is an independent-user written program in STATA for one-way random effects estimations of seemingly unrelated regressions in unbalanced panel data (Biørn, 2004; Nguyen \& Nguyen, 2010). However, it does not allow to impose the adding up condition to satisfy that $L_{i t}+I_{i t}+E_{i t}+R_{i t}=1$. ${ }^{23}$ Note that these pooled SURE estimations that exclude country-specific fixed effects are not the same as random effects estimations. The latter uses a weighted average of between- and within-country variations.
} 
For comparability, if Hausman specification tests favor the use of fixed effects in the first estimations, then country-specific fixed effects are also included as dummy variables in the system of equations. If random effects are favored, the system of equations is estimated as a pooled SURE without country dummies but keeping the time fixed effects. Hereafter, when it is stated that country-specific fixed effects are excluded, it refers to random effects in the case where the dependent variable is the compliance index; or pooled SURE in the case where the shares of waste treatment are modeled as a system of equations.

The estimations above assume a linear specification of its regressors. Alternative functional forms, like a quadratic form of income as in EKC studies, may complicate the interpretation of the coefficients because what the SURE models reflect is the substitution dynamics between waste treatment alternatives. In this case, an EKC hypothesis would be required for each ladder in the EWH. An inverted $U$ shaped relationship between income and the share of landfilling may be wanted for landfilling. However, it is ambiguous how to frame further hypotheses concerning alternative waste treatment methods like WtE that is between landfilling and recycling.

\section{Results}

Results of the sensitivity analysis of scenarios with different weighting coefficients for the compliance index show that all statistically significant relationships hold in all scenarios. However, Hausman specification tests for the first group of estimations favor country fixed effects only for the anti-landfill scenario, and random effects for the baseline and remaining scenarios. See Appendices $C$ and $D$. Therefore, the anti-landfill scenario is the reference to analyze the results using country fixed effects in Table 3, and the baseline scenario to analyze the results without country fixed effects in Table $4 .^{24}$ The dotted line separates the first estimation (in the left) and the SURE models (in the

\footnotetext{
${ }^{24}$ For reference, if the shares of waste treatment are modeled separately, i.e., not as a system of equations, Hausman specification tests favor random effects models for all waste treatment methods, except for the share of landfilling. See Appendices E and F.
} 
right). These are analyzed in conjunction, since compliance is a result of the waste treatment mix.

Table 3: Regressions results with country fixed effects

\begin{tabular}{|c|c|c|c|c|c|}
\hline & \multirow{3}{*}{\begin{tabular}{|c|c}
$(\mathrm{FE})$ \\
Compliance \\
$\left(\mathrm{W}_{\mathrm{D}}=1 ; \mathrm{W}_{\mathrm{E}}=3 ; \mathrm{W}_{\mathrm{R}}=4\right)$
\end{tabular}} & \multicolumn{4}{|c|}{ Seemingly unrelated regression equations (SURE) } \\
\hline & & \multicolumn{4}{|c|}{ \% shares of: } \\
\hline & & Landfilling & Incineration & WtE & Recycling \\
\hline $\begin{array}{l}\text { GDP per capita } \\
\text { (2010 EUR x 1000) }\end{array}$ & $\begin{array}{l}0.0245^{* *} \\
(0.00983)\end{array}$ & $\begin{array}{l}-1.162 \\
(1.810)\end{array}$ & $\begin{array}{l}0.146 \\
(0.199)\end{array}$ & $\begin{array}{l}0.602 \\
(1.006)\end{array}$ & $\begin{array}{l}0.414 \\
(1.367)\end{array}$ \\
\hline $\begin{array}{l}\text { Environmental regulation } \\
\text { (S\&E) }\end{array}$ & $\begin{array}{l}0.158^{*} \\
(0.0810)\end{array}$ & $\begin{array}{l}-6.671^{* *} \\
(3.068)\end{array}$ & $\begin{array}{l}1.056 \\
(0.736)\end{array}$ & $\begin{array}{l}1.026 \\
(2.239)\end{array}$ & $\begin{array}{l}4.589 \\
(3.798)\end{array}$ \\
\hline $\begin{array}{l}\text { Population density } \\
\text { (persons } / \mathrm{km}^{2} \text { ) }\end{array}$ & $\begin{array}{l}-0.0124 \\
(0.00990)\end{array}$ & $\begin{array}{l}0.701^{*} \\
(0.423)\end{array}$ & $\begin{array}{l}-0.175 \\
(0.138)\end{array}$ & $\begin{array}{l}-0.334 \\
(0.407)\end{array}$ & $\begin{array}{l}-0.193 \\
(0.516)\end{array}$ \\
\hline Heating degree days & $\begin{array}{l}-0.000357 \\
(0.000237)\end{array}$ & $\begin{array}{l}0.0130 \\
(0.00868)\end{array}$ & $\begin{array}{l}0.000515 \\
(0.00155)\end{array}$ & $\begin{array}{l}-0.00482 \\
(0.00570)\end{array}$ & $\begin{array}{l}-0.00870 \\
(0.0107)\end{array}$ \\
\hline $\begin{array}{l}\text { Electricity price } \\
\text { (cent.EUR/kWh) }\end{array}$ & $\begin{array}{l}-0.00691 \\
(0.0137)\end{array}$ & $\begin{array}{l}0.0481 \\
(0.788)\end{array}$ & $\begin{array}{l}0.160 \\
(0.217)\end{array}$ & $\begin{array}{l}0.0675 \\
(0.792)\end{array}$ & $\begin{array}{l}-0.275 \\
(0.938)\end{array}$ \\
\hline Years (Ref: 2016) & & & & & \\
\hline 2010 & $\begin{array}{l}-0.132 \\
(0.0991)\end{array}$ & $\begin{array}{l}3.093 \\
(4.193)\end{array}$ & $\begin{array}{l}1.568^{*} \\
(0.925)\end{array}$ & $\begin{array}{l}-0.744 \\
(3.249)\end{array}$ & $\begin{array}{l}-3.917 \\
(5.637)\end{array}$ \\
\hline 2012 & $\begin{array}{l}-0.135^{* *} \\
(0.0626)\end{array}$ & $\begin{array}{l}3.838 \\
(2.889)\end{array}$ & $\begin{array}{l}0.590 \\
(0.647)\end{array}$ & $\begin{array}{l}0.256 \\
(2.151)\end{array}$ & $\begin{array}{l}-4.684 \\
(3.590)\end{array}$ \\
\hline 2014 & $\begin{array}{l}-0.207^{* *} \\
(0.0884)\end{array}$ & $\begin{array}{l}6.268^{*} \\
(3.717)\end{array}$ & $\begin{array}{l}0.555 \\
(0.629)\end{array}$ & $\begin{array}{l}0.215 \\
(2.167)\end{array}$ & $\begin{array}{l}-7.038^{*} \\
(4.232)\end{array}$ \\
\hline Constant & $\begin{array}{l}3.476^{* *} \\
(1.631)\end{array}$ & $\begin{array}{l}12.37 \\
(118.0)\end{array}$ & $\begin{array}{l}-1.017 \\
(20.99)\end{array}$ & $\begin{array}{l}31.55 \\
(75.99)\end{array}$ & $\begin{array}{l}57.10 \\
(99.21)\end{array}$ \\
\hline Observations & 104 & 104 & 104 & 104 & 104 \\
\hline Number of countries & 26 & 26 & 26 & 26 & 26 \\
\hline Country fixed effects & YES & YES & YES & YES & YES \\
\hline$R^{2}$ & 0.448 & 0.958 & 0.782 & 0.914 & 0.888 \\
\hline
\end{tabular}


Table 4: Regressions results without country fixed effects

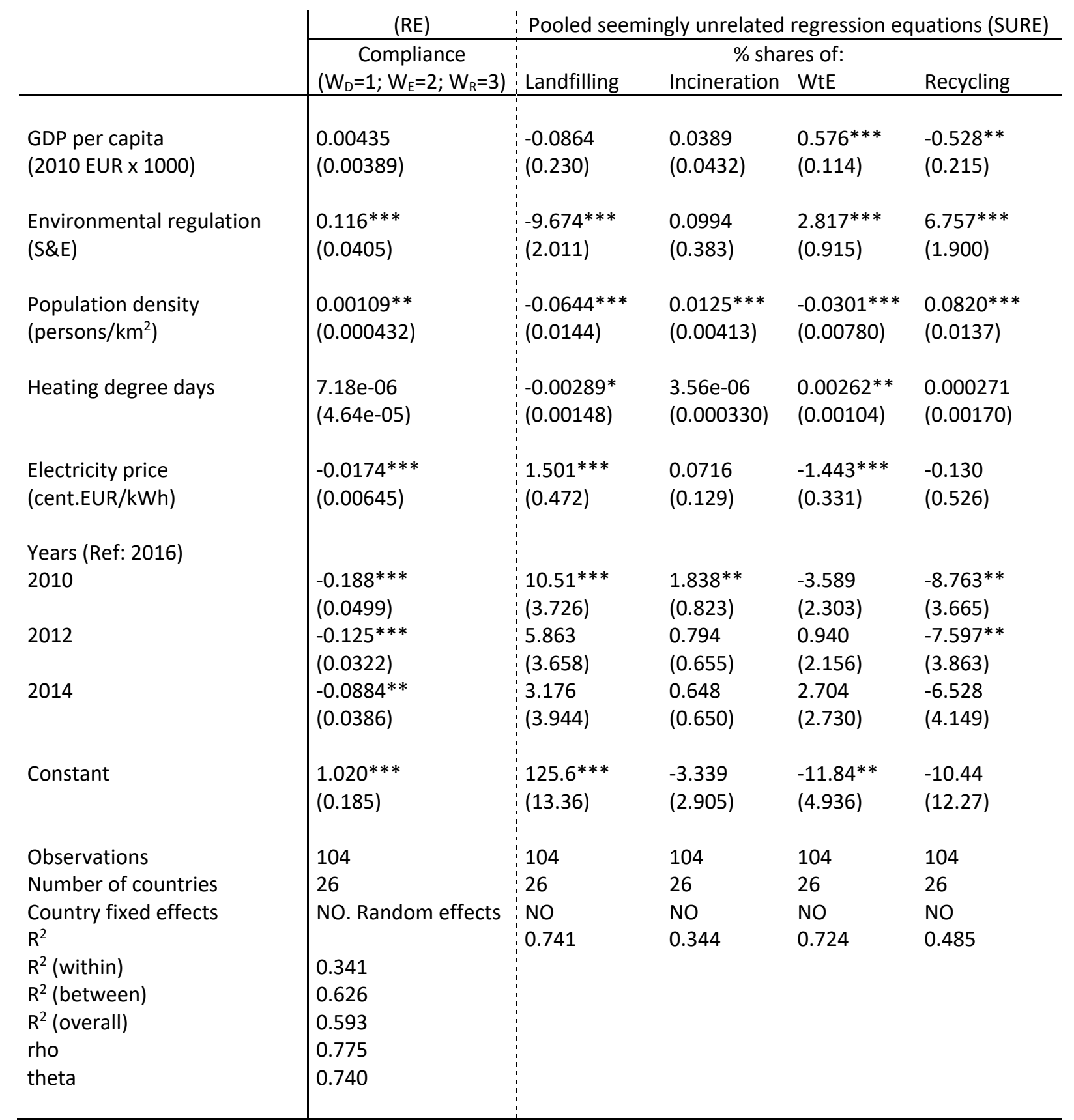

Robust standard errors in parentheses

$* * * p<0.01, * * p<0.05, * p<0.1$

If country fixed effects are included, results in Table 3 show that income and the S\&E of environmental regulation have a positive effect on compliance with the $\mathrm{EWH}$, and that compliance is higher in 2016 compared to previous years. Results from the SURE estimations show that the positive relationship with S\&E is mainly driven because a higher stringency and enforcement of environmental regulations is associated with a decrease in the share of landfilling. One point increase (on a scale of 14 ) in the S\&E of 
environmental regulation represents a decrease of 7 percentage units in the share of landfilling. ${ }^{25}$ In the case of income, there is a negative relationship with the share of landfilling and a positive relationship with incineration, $\mathrm{WtE}$, and recycling. However, bootstrapped standard errors do not show statistical significance. Higher compliance in 2016 may be explained by less landfilling compared to 2014, less incineration compared to 2010, and more recycling compared to 2014.

Results in Table 4 do not include country-specific fixed effects to highlight the variation between countries in the variables of interest. The following subsections analyze the results in Table 4 for each of the analyzed country characteristics.

Income

Changes in waste treatment due to income are driven by changes in social preferences towards the environment due to decreasing marginal utility, and also because income facilitates investments in technology and infrastructure required by, for example, WtE or recycling. In this study, the environmental regulation S\&E indicator aims to capture social preferences towards the environment. Therefore, the effect of income can be interpreted mainly as the technological progress component.

The relationship between income and compliance with the EWH is positive but statistically insignificant if country dummies are not included. See Table 4 . This result may be explained because the relationship between GDP per capita and the shares of $\mathrm{WtE}$ and recycling is positive and negative, respectively. A 1,000 EUR increase in GDP per capita represents an increase of 0.6 percentage units in the share of $\mathrm{WtE}$, but also a decrease of 0.5 percentage units in the share of recycling. These results indicate that as income increases, WtE replaces recycling. The technological component of WtE may explain this outcome, since income mainly reveals the technological progress component, as stated above.

\footnotetext{
${ }^{25}$ In context, an increase of one point in the S\&E score may be substantial for one country considering that the within standard deviation of the S\&E indicator is 0.35 . On the other hand, comparing countries, the between and overall standard deviations are 1.8. See Table 2.
} 
Previous literature shows a negative relationship between income and recycling, e.g., Huhtala (1999) argues that the opportunity cost of time spent on recycling efforts increases with income. However, Huhtala's work is from the household's perspective. From a country perspective, the results from this study suggest that as income increases, the relative costs and benefits of $\mathrm{WtE}$ make recycling less attractive.

\section{Stringency and enforcement of environmental regulation}

Results in Table 4 show a positive relationship between regulatory S\&E and compliance with the EWH, mainly driven by a negative relationship between S\&E and the share of landfilling, and a positive relationship with the shares of WtE and recycling. One point increase (on a scale of 14 ) in the S\&E of environmental regulation represents a decrease of 10 percentage units in the share of landfilling and an increase of 3 and 7 percentage units in the shares of WtE and recycling, respectively. Therefore, higher S\&E of environmental regulations promote the substitution of landfilling with WtE and recycling. In this case, landfilling is costly for society, so stringent and enforceable environmental regulations to replace landfilling are supported. These results complement previous studies by Antonioli et al. (2018) and Mazzanti \& Zoboli (2008), who used other indicators to capture the effect of environmental policy.

\section{Population density}

Population density does not change much over time, but it differs between countries. Results in Table 4 show a positive relationship between population density and compliance with the EWH. Concerning the waste treatment mix, population density has a negative relationship with landfilling and $\mathrm{WtE}$, and a positive relationship with incineration and recycling. These relations mean that an increase in population favors incineration and recycling over landfilling and $\mathrm{WtE}$. Land competition and the relative cost of space justify the negative relationship with landfilling in favor of alternative methods like incineration. This positive relationship with incineration is compatible with previous studies like Antonioli et al. (2018) and Mazzanti \& Zoboli (2008). Economies of 
scale for sorting and collection explains the positive relationship with recycling. A positive relationship with recycling has also been observed in previous studies by Berglund et al. (2002) and Karousakis (2009). The negative relationship with WtE may be explained because the costs and benefits are higher, in relative terms, compared to incineration and recycling.

\section{Heating demand}

Results support the expected positive relationship between heating demand (represented by heating degree days) and the share of WtE. WtE plants are mainly intended to generate heat for local district heating networks and when the weather is cold, the relative utility of heat increases. Results also show a negative relationship between heating degree days and the share of landfilling. In this case, higher demand for heating stimulates the substitution of landfilled waste in favor of WtE.

\section{Electricity prices}

As noted in the introductory section, a positive relationship between electricity prices and the share of $\mathrm{WtE}$ is expected because electricity can be a byproduct of CHP plants, and also because district heating from WtE competes with other heat alternatives that use electricity like heat pumps. This positive relationship holds if country fixed effects are included, but the effect is not statistically significant. See Table 3. If country fixed effects are excluded, the relationship between electricity prices and the share of WtE becomes negative, together with a positive relationship with the share of landfilling. See Table 4. This unexpected outcome may be explained by the fact that, among other reasons, investments in WtE require time, and the timeframe in this paper's dataset may not fully capture these long-term relationships.

\section{Time trends}

Compliance with the EWH has improved over time, which suggests a positive effect of the Waste Framework Directive from 2008. The shares of landfilling and incineration 
were $11 \%$ and $2 \%$, respectively, higher in 2010 compared to 2016, while the share of recycling was $9 \%$ lower.

\section{Conclusions and discussion}

Countries treat waste based on the relative costs of different waste treatment options. This paper estimated the effect of income, the stringency and enforcement of environmental regulation, population density, heating demand, and electricity prices in the waste treatment mix and compliance with the EWH. The research shows that these country characteristics affect the relative costs and benefits of waste treatment options, and therefore compliance with the EWH. This paper adds to the literature by constructing a waste hierarchy compliance index, which is regressed in these country characteristics. A better understanding of these determinants provides useful insights for the design of EU waste policy.

This paper illustrates that stringency and enforcement of environmental regulations matter. The positive effect of environmental regulation S\&E on compliance with the EWH is robust regardless of whether country fixed effects are included in the econometric estimations. Higher compliance mainly occurs because S\&E has led to a reduction in the share of landfilling. Moreover, a positive relationship between S\&E and the shares of WtE and recycling is also observed in the pooled SURE case. If social preferences are in line with the objectives of the EWH, society will strive for stringent and enforceable regulations to increase compliance with the EWH. This is a process that requires time. This study also reveals that compliance with the EWH has improved over time.

One limitation of this study is that the S\&E indicator refers to environmental regulations in general and is not specific to waste management. Further research assessing specific waste policies could enable specific suggestions to be made about which policy instruments improve compliance in different contexts. The extent to which waste policies should be stringent or enforceable is a question for future research. What this study can show from the WEF survey is that stringency is perceived as more rigorous 
than enforcement. Future studies can test the pollution haven and Porter hypotheses in the context of waste management.

The present study is unique in addressing the effect of heating demand and electricity prices on the share of WtE. WtE plants provide not only energy in forms of heat and electricity, but also a waste treatment service that the EWH ranks between disposal and recycling. The links between the heat, electricity, and waste markets make WtE an important case for further research, particularly concerning its comprehensive benefits and costs. Olsson, Wetterlund, \& Söderström (2015) highlighted the lack of consensus on the climate impact of district heating systems given its sensitivity to the assessment method and local conditions. The results from the pooled SURE show a positive relationship between $\mathrm{WtE}$ and demand for heating. This outcome implies that the relative value of WtE is higher in colder countries with already installed WtE capacity. However, results also show an unexpected negative relationship between the share of WtE electricity prices. The limited timeframe may influence this result. Future studies with more extended time series are required.

The compliance index developed herein adds to the existing literature and is designed to reflect the hierarchy in the EWH. Still, future research can be undertaken to improve these types of indexes. Ideally, an index of this kind can use weights that reflect the costoptimality of waste treatment methods, a feature that the EWH does not necessarily reflect. Another limitation of the EWH compliance index used here is that it does not reflect waste reduction, the top priority in the EWH. Further research can help to fill this gap.

Last but not least, this study and its results rely on the data quality of its sources. Countries report to Eurostat based on a harmonized methodology, but it is not entirely free from faults. Audit processes are recommended due to the importance of these types of datasets for research and policy. 
APPENDICES

Appendix A:

Waste Hierarchy under EU's Directive 2008/98/EC on Waste

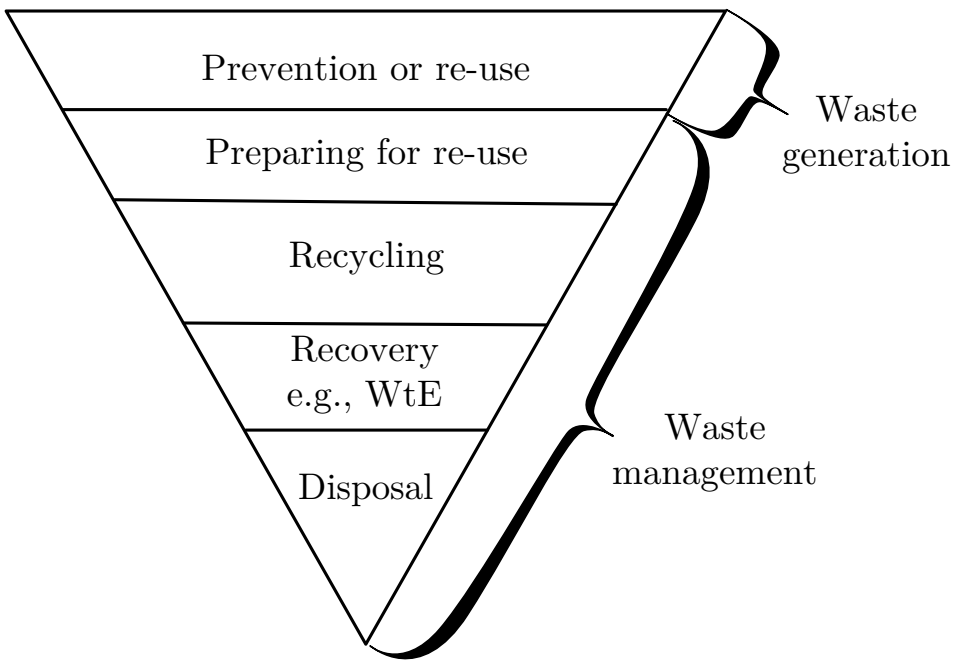




\section{Appendix B:}

\section{Environmental policy stringency and enforcement scores}

\section{Stringency:}

How do you assess the stringency of your country's environmental regulations?

\section{Enforcement:}

In your country, how do you assess the enforcement of environmental regulations?

[ 1 = Very lax - among the worst in the world; 7 = Among the world's most rigorous $]$ (Sample size in parenthesis)

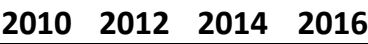

\begin{tabular}{|c|c|c|c|c|}
\hline \multicolumn{5}{|l|}{ Austria } \\
\hline Stringency & 6.45 & 6.28 & 6.20 & 6.18 \\
\hline \multirow[t]{2}{*}{ Enforcement } & 6.17 & 5.88 & 5.99 & 6.08 \\
\hline & (80) & $(105)$ & (71) & (111) \\
\hline \multicolumn{5}{|l|}{ Belgium } \\
\hline Stringency & 5.89 & 5.81 & 6.00 & 5.50 \\
\hline \multirow[t]{2}{*}{ Enforcement } & 5.45 & 5.47 & 5.63 & 5.16 \\
\hline & (76) & (83) & (64) & (51) \\
\hline \multicolumn{5}{|l|}{ Bulgaria } \\
\hline Stringency & 2.98 & 3.37 & 3.47 & 3.59 \\
\hline \multirow[t]{2}{*}{ Enforcement } & 2.81 & 3.25 & 3.26 & 3.27 \\
\hline & (115) & $(120)$ & $(104)$ & (116) \\
\hline \multicolumn{5}{|l|}{ Croatia } \\
\hline Stringency & 4.37 & 4.31 & 4.52 & 4.42 \\
\hline \multirow[t]{2}{*}{ Enforcement } & 3.71 & 3.53 & 4.05 & 4.12 \\
\hline & (97) & $(107)$ & (82) & (85) \\
\hline \multicolumn{5}{|l|}{ Cyprus } \\
\hline Stringency & 4.35 & 4.20 & 4.70 & 4.00 \\
\hline \multirow[t]{2}{*}{ Enforcement } & 4.2 & 3.98 & 4.47 & 4.06 \\
\hline & (95) & (79) & (52) & (65) \\
\hline \multicolumn{5}{|l|}{ Czechia } \\
\hline Stringency & 5.26 & 5.24 & 5.13 & 5.20 \\
\hline \multirow[t]{2}{*}{ Enforcement } & 4.8 & 4.69 & 4.71 & 4.43 \\
\hline & (78) & $(163)$ & (77) & (106) \\
\hline \multicolumn{5}{|l|}{ Denmark } \\
\hline Stringency & 6.00 & 6.15 & 6.34 & 5.81 \\
\hline \multirow[t]{2}{*}{ Enforcement } & 6.05 & 6.09 & 6.24 & 5.97 \\
\hline & (35) & $(128)$ & (89) & (110) \\
\hline \multicolumn{5}{|l|}{ Estonia } \\
\hline Stringency & 5.31 & 5.37 & 5.37 & 5.37 \\
\hline \multirow[t]{2}{*}{ Enforcement } & 4.92 & 5.17 & 5.26 & 5.33 \\
\hline & (87) & (85) & (89) & (89) \\
\hline \multicolumn{5}{|l|}{ Finland } \\
\hline Stringency & 6.13 & 6.42 & 6.22 & 6.21 \\
\hline Enforcement & 6.03 & 6.38 & 6.26 & 6.21 \\
\hline
\end{tabular}


France

$\begin{array}{lllll}\text { Stringency } & 5.27 & 5.10 & 5.17 & 5.12\end{array}$

$\begin{array}{lllll}\text { Enforcement } \quad 5 & 4.76 & 4.9 & 4.89\end{array}$

(128) (129) (184) (94)

Germany

$\begin{array}{lllll}\text { Stringency } & 6.62 & 6.44 & 6.14 & 6.01\end{array}$

$\begin{array}{lllll}\text { Enforcement } & 6.38 & 6.21 & 6.08 & 5.7\end{array}$

(68) (127) (99) (103)

Greece

$\begin{array}{lllll}\text { Stringency } & 3.63 & 3.71 & 4.04 & 4.43\end{array}$

$\begin{array}{lllll}\text { Enforcement } & 3.08 & 2.93 & 3.47 & 3.78\end{array}$

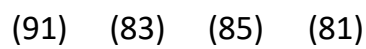

Hungary

$\begin{array}{lllll}\text { Stringency } & 4.68 & 4.78 & 4.68 & 3.98\end{array}$

$\begin{array}{lllll}\text { Enforcement } & 3.5 & 3.52 & 3.83 & 3.42\end{array}$

(81) (103) (99) (52)

Ireland

$\begin{array}{lllll}\text { Stringency } & 5.26 & 5.62 & 5.36 & 5.23\end{array}$

$\begin{array}{lllll}\text { Enforcement } \quad 5.06 & 5.28 & 5.07 & 5.13\end{array}$

(48) (62) (52) (38)

Italy

$\begin{array}{lllll}\text { Stringency } & 4.15 & 4.48 & 4.80 & 4.46\end{array}$

$\begin{array}{lllll}\text { Enforcement } & 3.3 & 3.42 & 3.85 & 3.64\end{array}$

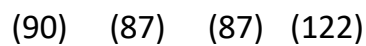

Latvia

$\begin{array}{lllll}\text { Stringency } & 4.26 & 4.42 & 4.92 & 4.70\end{array}$

$\begin{array}{lllll}\text { Enforcement } & 3.92 & 4.17 & 4.69 & 4.43\end{array}$

(138) (98) (81) (89)

Lithuania

$\begin{array}{lllll}\text { Stringency } & 4.93 & 4.82 & 5.01 & 4.93\end{array}$

$\begin{array}{lllll}\text { Enforcement } \quad 4.3 & 4.19 & 4.62 & 4.7\end{array}$

(137) (153) (146) (121)

Netherlands

$\begin{array}{lllll}\text { Stringency } & 6.09 & 6.04 & 5.84 & 5.78\end{array}$

$\begin{array}{lllll}\text { Enforcement } \quad 5.93 & 5.88 & 5.73 & 5.6\end{array}$

(99) (82) (88) (75)

Poland

$\begin{array}{lllll}\text { Stringency } & 4.61 & 4.83 & 4.64 & 4.46\end{array}$

$\begin{array}{lllll}\text { Enforcement } & 4.16 & 4.17 & 4.06 & 3.79\end{array}$

(311) (206) (200) (206)

Portugal

$\begin{array}{lllll}\text { Stringency } & 5.22 & 5.20 & 5.43 & 5.25\end{array}$

$\begin{array}{lllll}\text { Enforcement } \quad 4.2 & 4.33 & 4.89 & 4.75\end{array}$

(103) (115) (140) (220)

Romania

$\begin{array}{lllll}\text { Stringency } & 3.69 & 3.19 & 3.75 & 3.81\end{array}$

$\begin{array}{lllll}\text { Enforcement } & 3.24 & 3.01 & 3.67 & 3.29\end{array}$

$(100) \quad(98) \quad(72) \quad(100)$ 
$\begin{array}{llll}2010 & 2012 & 2014 & 2016\end{array}$

\begin{tabular}{rrrrr}
\hline Slovakia & & & & \\
Stringency & 5.16 & 4.70 & 4.89 & 4.91 \\
Enforcement & 3.94 & 3.8 & 4.08 & 4.11 \\
& $(62)$ & $(68)$ & $(85)$ & $(109)$ \\
Slovenia & & & & \\
Stringency & 5.02 & 5.07 & 5.18 & 5.38 \\
Enforcement & 4.4 & 4.48 & 4.79 & 4.85 \\
& $(101)$ & $(110)$ & $(84)$ & $(85)$ \\
Spain & & & & \\
Stringency & 4.82 & 4.82 & 4.55 & 4.78 \\
Enforcement & 4.22 & 4.5 & 4.3 & 4.68 \\
& $(177)$ & $(91)$ & $(76)$ & $(104)$ \\
Sweden & & & & \\
Stringency & 6.46 & 6.12 & 5.87 & 6.22 \\
Enforcement & 6.36 & 6.07 & 5.78 & 6.07 \\
& $(37)$ & $(77)$ & $(62)$ & $(54)$ \\
United Kingdom & & & & \\
Stringency & 5.43 & 5.46 & 5.45 & 5.38 \\
Enforcement & 5.2 & 5.43 & 5.32 & 5.26 \\
& $(102)$ & $(102)$ & $(79)$ & $(73)$ \\
\hline
\end{tabular}

Source: WEF (2018) 
Appendix C:

Sensitivity analysis for the compliance index (Fixed effects)

\begin{tabular}{|c|c|c|c|c|}
\hline & \multicolumn{4}{|c|}{ Compliance index (CI) } \\
\hline & $\begin{array}{l}W_{D}=1 \\
W_{E}=2 \\
W_{R}=3\end{array}$ & $\begin{array}{l}W_{D}=1 \\
W_{E}=2 \\
W_{R}=4\end{array}$ & $\begin{array}{l}W_{D}=1 \\
W_{E}=3 \\
W_{R}=4\end{array}$ & $\begin{array}{l}W_{D}=1 \\
W_{E}=3 \\
W_{R}=6\end{array}$ \\
\hline $\begin{array}{l}\text { GDP per capita } \\
\text { (2010 EUR x 1000) }\end{array}$ & $\begin{array}{l}0.0143 * * \\
(0.00653)\end{array}$ & $\begin{array}{l}0.0184 * \\
(0.00982)\end{array}$ & $\begin{array}{l}0.0245^{* *} \\
(0.00983)\end{array}$ & $\begin{array}{l}0.0327^{*} \\
(0.0163)\end{array}$ \\
\hline $\begin{array}{l}\text { Environmental regulation } \\
\text { (S\&E) }\end{array}$ & $\begin{array}{l}0.102^{*} \\
(0.0551)\end{array}$ & $\begin{array}{l}0.148^{*} \\
(0.0852)\end{array}$ & $\begin{array}{l}0.158 * \\
(0.0810)\end{array}$ & $\begin{array}{l}0.250 * \\
(0.140)\end{array}$ \\
\hline $\begin{array}{l}\text { Population density } \\
\text { (persons } / \mathrm{km}^{2} \text { ) }\end{array}$ & $\begin{array}{l}-0.00719 \\
(0.00697)\end{array}$ & $\begin{array}{l}-0.00911 \\
(0.0112)\end{array}$ & $\begin{array}{l}-0.0124 \\
(0.00990)\end{array}$ & $\begin{array}{l}-0.0163 \\
(0.0182)\end{array}$ \\
\hline Heating degree days & $\begin{array}{l}-0.000222 \\
(0.000166)\end{array}$ & $\begin{array}{l}-0.000309 \\
(0.000263)\end{array}$ & $\begin{array}{l}-0.000357 \\
(0.000237)\end{array}$ & $\begin{array}{l}-0.000531 \\
(0.000429)\end{array}$ \\
\hline $\begin{array}{l}\text { Electricity price } \\
\text { (cent.EUR/kWh) }\end{array}$ & $\begin{array}{l}-0.00483 \\
(0.00883)\end{array}$ & $\begin{array}{l}-0.00758 \\
(0.0134)\end{array}$ & $\begin{array}{l}-0.00691 \\
(0.0137)\end{array}$ & $\begin{array}{l}-0.0124 \\
(0.0221)\end{array}$ \\
\hline Years (Ref: 2016) & & & & \\
\hline 2010 & $\begin{array}{l}-0.0858 \\
(0.0717)\end{array}$ & $\begin{array}{l}-0.125 \\
(0.117)\end{array}$ & $\begin{array}{l}-0.132 \\
(0.0991)\end{array}$ & $\begin{array}{l}-0.211 \\
(0.189)\end{array}$ \\
\hline 2012 & $\begin{array}{l}-0.0911^{* *} \\
(0.0431)\end{array}$ & $\begin{array}{l}-0.138^{*} \\
(0.0679)\end{array}$ & $\begin{array}{l}-0.135^{* *} \\
(0.0626)\end{array}$ & $\begin{array}{l}-0.229 * * \\
(0.111)\end{array}$ \\
\hline 2014 & $\begin{array}{l}-0.139 * * \\
(0.0609)\end{array}$ & $\begin{array}{l}-0.209 * * \\
(0.0948)\end{array}$ & $\begin{array}{l}-0.207^{* *} \\
(0.0884)\end{array}$ & $\begin{array}{l}-0.348^{* *} \\
(0.156)\end{array}$ \\
\hline Constant & $\begin{array}{l}2.493^{* *} \\
(1.090)\end{array}$ & $\begin{array}{l}3.002 * \\
(1.662)\end{array}$ & $\begin{array}{l}3.476^{* *} \\
(1.631)\end{array}$ & $\begin{array}{l}4.495 \\
(2.747)\end{array}$ \\
\hline Observations & 104 & 104 & 104 & 104 \\
\hline $\mathrm{R}^{2}$ & 0.408 & 0.361 & 0.448 & 0.380 \\
\hline Number of countries & 26 & 26 & 26 & 26 \\
\hline Country fixed effects & YES & YES & YES & YES \\
\hline rho & 0.979 & 0.971 & 0.984 & 0.975 \\
\hline Hausman test $\left(\chi^{2}\right)$ & 10.55 & 8.57 & 12.58 & 9.35 \\
\hline Hausman test (Prob $\left.>\chi^{2}\right)$ & 0.0610 & 0.1274 & 0.0277 & 0.0960 \\
\hline
\end{tabular}

Robust standard errors in parentheses

$* * * p<0.01, * * p<0.05, * p<0.1$

The highlighted cells show that the Hausman test favors fixed effects. 
Appendix D:

Sensitivity analysis for the compliance index (Random effects)

\begin{tabular}{|c|c|c|c|c|}
\hline & \multicolumn{4}{|c|}{ Compliance index $(\mathrm{Cl})$} \\
\hline & $\begin{array}{l}W_{D}=1 \\
W_{E}=2 \\
W_{R}=3\end{array}$ & $\begin{array}{l}W_{D}=1 \\
W_{E}=2 \\
W_{R}=4\end{array}$ & $\begin{array}{l}W_{D}=1 \\
W_{E}=3 \\
W_{R}=4\end{array}$ & $\begin{array}{l}W_{D}=1 \\
W_{E}=3 \\
W_{R}=6\end{array}$ \\
\hline $\begin{array}{l}\text { GDP per capita } \\
(2010 \text { EUR } \times 1000)\end{array}$ & $\begin{array}{l}0.00435 \\
(0.00389)\end{array}$ & $\begin{array}{l}0.00306 \\
(0.00598)\end{array}$ & $\begin{array}{l}0.00994 * \\
(0.00580)\end{array}$ & $\begin{array}{l}0.00742 \\
(0.00985)\end{array}$ \\
\hline $\begin{array}{l}\text { Environmental regulation } \\
\text { (S\&E) }\end{array}$ & $\begin{array}{l}0.116 * * * \\
(0.0405)\end{array}$ & $\begin{array}{l}0.166 * * * \\
(0.0633)\end{array}$ & $\begin{array}{l}0.183^{* * *} \\
(0.0587)\end{array}$ & $\begin{array}{l}0.282^{* * *} \\
(0.104)\end{array}$ \\
\hline $\begin{array}{l}\text { Population density } \\
\text { (persons } / \mathrm{km}^{2} \text { ) }\end{array}$ & $\begin{array}{l}0.00109 * * \\
(0.000432)\end{array}$ & $\begin{array}{l}0.00184 * * * \\
(0.000665)\end{array}$ & $\begin{array}{l}0.00144 * * \\
(0.000642)\end{array}$ & $\begin{array}{l}0.00293 * * * \\
(0.00109)\end{array}$ \\
\hline Heating degree days & $\begin{array}{l}7.18 \mathrm{e}-06 \\
(4.64 \mathrm{e}-05)\end{array}$ & $\begin{array}{l}-2.97 e-07 \\
(6.87 e-05)\end{array}$ & $\begin{array}{l}2.20 \mathrm{e}-05 \\
(7.08 \mathrm{e}-05)\end{array}$ & $\begin{array}{l}6.89 \mathrm{e}-06 \\
(0.000115)\end{array}$ \\
\hline $\begin{array}{l}\text { Electricity price } \\
\text { (cent.EUR/kWh) }\end{array}$ & $\begin{array}{l}-0.0174 * * * \\
(0.00645)\end{array}$ & $\begin{array}{l}-0.0232 * * \\
(0.00982)\end{array}$ & $\begin{array}{l}-0.0290 * * * \\
(0.00981)\end{array}$ & $\begin{array}{l}-0.0407 * * \\
(0.0162)\end{array}$ \\
\hline Years (Ref: 2016) & & & & \\
\hline 2010 & $\begin{array}{l}-0.188^{* * *} \\
(0.0499)\end{array}$ & $\begin{array}{l}-0.266 * * * \\
(0.0782)\end{array}$ & $\begin{array}{l}-0.297 * * * \\
(0.0725)\end{array}$ & $\begin{array}{l}-0.454 * * * \\
(0.128)\end{array}$ \\
\hline 2012 & $\begin{array}{l}-0.125^{* * *} \\
(0.0322)\end{array}$ & $\begin{array}{l}-0.189 * * * \\
(0.0512)\end{array}$ & $\begin{array}{l}-0.187^{* * *} \\
(0.0471)\end{array}$ & $\begin{array}{l}-0.314 * * * \\
(0.0831)\end{array}$ \\
\hline 2014 & $\begin{array}{l}-0.0884^{* *} \\
(0.0386)\end{array}$ & $\begin{array}{l}-0.145^{* *} \\
(0.0580)\end{array}$ & $\begin{array}{l}-0.121^{* *} \\
(0.0589)\end{array}$ & $\begin{array}{l}-0.233^{* *} \\
(0.0963)\end{array}$ \\
\hline Constant & $\begin{array}{l}1.020 * * * \\
(0.185)\end{array}$ & $\begin{array}{l}1.088^{* * *} \\
(0.293)\end{array}$ & $\begin{array}{l}0.969 * * * \\
(0.266)\end{array}$ & $\begin{array}{l}1.108 * * \\
(0.477)\end{array}$ \\
\hline Observations & 104 & 104 & 104 & 104 \\
\hline Number of countries & 26 & 26 & 26 & 26 \\
\hline $\mathrm{R}^{2}$ (within) & 0.341 & 0.304 & 0.371 & 0.319 \\
\hline$R^{2}$ (between) & 0.626 & 0.588 & 0.660 & 0.604 \\
\hline $\mathrm{R}^{2}$ (overall) & 0.593 & 0.552 & 0.629 & 0.569 \\
\hline rho & 0.775 & 0.763 & 0.783 & 0.768 \\
\hline theta & 0.740 & 0.732 & 0.746 & 0.735 \\
\hline Hausman test $\left(\chi^{2}\right)$ & 10.55 & 8.57 & 12.58 & 9.35 \\
\hline Hausman test $\left(\right.$ Prob $\left.>\chi^{2}\right)$ & 0.0610 & 0.1274 & 0.0277 & 0.0960 \\
\hline
\end{tabular}

Robust standard errors in parentheses

$* * * p<0.01, * * p<0.05, * p<0.1$

The light-highlighted column shows the model with the highest $\mathrm{R}^{2}$ among the models where random effects are favored by the Hausman test.

The dark-highlighted cells show that the Hausman test favors random effects. 
Appendix E:

Regressions results

(Independent fixed effects models)

\begin{tabular}{|c|c|c|c|c|}
\hline & \multicolumn{4}{|c|}{ \% shares of: } \\
\hline & Landfilling & Incineration & WtE & Recycling \\
\hline $\begin{array}{l}\text { GDP per capita } \\
(2010 \text { EUR } \times 1000)\end{array}$ & $\begin{array}{l}-1.162 * * * \\
(0.332)\end{array}$ & $\begin{array}{l}0.146 * * * \\
(0.0402)\end{array}$ & $\begin{array}{l}0.602 * * * \\
(0.160)\end{array}$ & $\begin{array}{l}0.414 \\
(0.336)\end{array}$ \\
\hline $\begin{array}{l}\text { Environmental regulation } \\
\text { (S\&E) }\end{array}$ & $\begin{array}{l}-6.671 * * \\
(2.751)\end{array}$ & $\begin{array}{l}1.056 \\
(0.666)\end{array}$ & $\begin{array}{l}1.026 \\
(1.799)\end{array}$ & $\begin{array}{l}4.589 \\
(3.093)\end{array}$ \\
\hline $\begin{array}{l}\text { Population density } \\
\text { (persons } / \mathrm{km}^{2} \text { ) }\end{array}$ & $\begin{array}{l}0.701^{* *} \\
(0.340)\end{array}$ & $\begin{array}{l}-0.175^{*} \\
(0.100)\end{array}$ & $\begin{array}{l}-0.334 \\
(0.316)\end{array}$ & $\begin{array}{l}-0.193 \\
(0.439)\end{array}$ \\
\hline Heating degree days & $\begin{array}{l}0.0130 * \\
(0.00668)\end{array}$ & $\begin{array}{l}0.000515 \\
(0.00102)\end{array}$ & $\begin{array}{l}-0.00482 \\
(0.00403)\end{array}$ & $\begin{array}{l}-0.00870 \\
(0.00974)\end{array}$ \\
\hline $\begin{array}{l}\text { Electricity price } \\
\text { (cent.EUR/kWh) }\end{array}$ & $\begin{array}{l}0.0481 \\
(0.548)\end{array}$ & $\begin{array}{l}0.160 \\
(0.144)\end{array}$ & $\begin{array}{l}0.0675 \\
(0.591)\end{array}$ & $\begin{array}{l}-0.275 \\
(0.518)\end{array}$ \\
\hline Years (Ref: 2016) & & & & \\
\hline 2010 & $\begin{array}{l}3.093 \\
(2.740)\end{array}$ & $\begin{array}{l}1.568 * * \\
(0.694)\end{array}$ & $\begin{array}{l}-0.744 \\
(2.633)\end{array}$ & $\begin{array}{l}-3.917 \\
(4.585)\end{array}$ \\
\hline 2012 & $\begin{array}{l}3.838^{*} \\
(2.041)\end{array}$ & $\begin{array}{l}0.590 \\
(0.462)\end{array}$ & $\begin{array}{l}0.256 \\
(1.854)\end{array}$ & $\begin{array}{l}-4.684^{*} \\
(2.582)\end{array}$ \\
\hline 2014 & $\begin{array}{l}6.268 * * \\
(2.758)\end{array}$ & $\begin{array}{l}0.555 \\
(0.330)\end{array}$ & $\begin{array}{l}0.215 \\
(1.543)\end{array}$ & $\begin{array}{l}-7.038 * \\
(3.438)\end{array}$ \\
\hline Constant & $\begin{array}{l}-4.583 \\
(58.51)\end{array}$ & $\begin{array}{l}6.265 \\
(14.99)\end{array}$ & $\begin{array}{l}47.36 \\
(39.55)\end{array}$ & $\begin{array}{l}50.96 \\
(59.39)\end{array}$ \\
\hline Observations & 104 & 104 & 104 & 104 \\
\hline $\mathrm{R}^{2}$ (within) & 0.487 & 0.255 & 0.187 & 0.261 \\
\hline Number of countries & 26 & 26 & 26 & 26 \\
\hline rho & 0.993 & 0.992 & 0.976 & 0.939 \\
\hline Hausman test $\left(\chi^{2}\right)$ & 16.93 & 8.54 & 9.09 & 5.33 \\
\hline Hausman test $\left(\right.$ Prob $\left.>\chi^{2}\right)$ & 0.0046 & 0.1287 & 0.1056 & 0.3775 \\
\hline
\end{tabular}

The highlighted cells show that the Hausman test favors fixed effects. 
Appendix F:

Regressions results

(Independent random effects models)

\begin{tabular}{|c|c|c|c|c|}
\hline & \multicolumn{4}{|c|}{ \% shares of: } \\
\hline & Landfilling & Incineration & WtE & Recycling \\
\hline GDP per capita & $-0.546 * * *$ & -0.00591 & $0.589 * * *$ & -0.130 \\
\hline (2010 EUR x 1000) & (0.197) & $(0.0574)$ & $(0.151)$ & $(0.218)$ \\
\hline \multirow{2}{*}{$\begin{array}{l}\text { Environmental regulation } \\
\text { (S\&E) }\end{array}$} & $-7.489 * * *$ & 0.565 & $2.154^{*}$ & $4.952 * *$ \\
\hline & $(2.020)$ & $(0.501)$ & (1.173) & $(2.309)$ \\
\hline \multirow{2}{*}{$\begin{array}{l}\text { Population density } \\
\text { (persons } / \mathrm{km}^{2} \text { ) }\end{array}$} & $-0.0434 *$ & $0.0110 *$ & $-0.0327 * *$ & $0.0746 * * *$ \\
\hline & $(0.0227)$ & $(0.00582)$ & $(0.0147)$ & $(0.0241)$ \\
\hline \multirow[t]{2}{*}{ Heating degree days } & -0.00120 & -0.000182 & $0.00314 * *$ & -0.000782 \\
\hline & $(0.00253)$ & $(0.000499)$ & $(0.00152)$ & $(0.00231)$ \\
\hline Electricity price & $1.016 * * *$ & 0.117 & $-0.827 * * *$ & -0.561 \\
\hline (cent.EUR/kWh) & $(0.369)$ & $(0.152)$ & $(0.292)$ & $(0.363)$ \\
\hline \multicolumn{5}{|l|}{ Years (Ref: 2016) } \\
\hline \multirow[t]{2}{*}{2010} & $9.054 * * *$ & $1.868 * *$ & $-3.714 * *$ & $-7.805^{* * *}$ \\
\hline & $(2.406)$ & $(0.818)$ & $(1.847)$ & $(2.918)$ \\
\hline \multirow[t]{2}{*}{2012} & $5.450 * * *$ & 0.727 & 0.166 & $-6.381 * * *$ \\
\hline & $(1.692)$ & $(0.538)$ & $(1.859)$ & $(2.037)$ \\
\hline \multirow[t]{2}{*}{2014} & 2.889 & 0.431 & 2.567 & $-5.648 * * *$ \\
\hline & (2.147) & $(0.313)$ & $(1.766)$ & $(2.060)$ \\
\hline \multirow[t]{2}{*}{ Constant } & $113.6^{* * *}$ & $-6.615^{*}$ & $-14.23 * *$ & 6.762 \\
\hline & $(8.874)$ & $(3.710)$ & $(6.389)$ & (11.10) \\
\hline Observations & 104 & 104 & 104 & 104 \\
\hline Number of countries & 26 & 26 & 26 & 26 \\
\hline $\mathrm{R}^{2}$ (within) & 0.379 & 0.179 & 0.118 & 0.224 \\
\hline $\mathrm{R}^{2}$ (between) & 0.730 & 0.390 & 0.783 & 0.503 \\
\hline $\mathrm{R}^{2}$ (overall) & 0.701 & 0.327 & 0.710 & 0.461 \\
\hline rho & 0.799 & 0.576 & 0.598 & 0.735 \\
\hline theta & 0.757 & 0.606 & 0.621 & 0.712 \\
\hline Hausman test $\left(\chi^{2}\right)$ & 16.93 & 8.54 & 9.09 & 5.33 \\
\hline Hausman test (Prob $\left.>\chi^{2}\right)$ & 0.0046 & 0.1287 & 0.1056 & 0.3775 \\
\hline
\end{tabular}

Robust standard errors in parentheses

$* * * \mathrm{p}<0.01, * * \mathrm{p}<0.05, * \mathrm{p}<0.1$

The highlighted cells show that the Hausman test favors random effects. 


\section{References}

Antonioli, D., Caratù, F., \& Nicolli, F. (2018). Waste performance, waste technology and policy effects. Journal of Environmental Planning and Management. https://doi.org/10.1080/09640568.2017.1336431

Berglund, C., \& Söderholm, P. (2003). An econometric analysis of global waste paper recovery and utilization. Environmental and Resource Economics. https://doi.org/10.1023/B:EARE.0000003595.60196.a9

Berglund, C., Söderholm, P., \& Nilsson, M. (2002). A note on inter-country differences in waste paper recovery and utilization. Resources, Conservation and Recycling. https://doi.org/10.1016/S0921-3449(01)00101-X

Biørn, E. (2004). Regression systems for unbalanced panel data: A stepwise maximum likelihood procedure. Journal of Econometrics. https://doi.org/10.1016/j.jeconom.2003.10.023

Brisson, I. E. (1997). Assessing the waste hierarchy: A social cost benefit analysis of municipal solid waste management in the European Union. Samfund, Økonomi and Miljø. Denmark: AKF Forlaget, 19.

Brunel, C., \& Levinson, A. (2016). Measuring the stringency of environmental regulations. Review of Environmental Economics and Policy. https://doi.org/10.1093/reep/rev019

Cameron, A. C., \& Trivedi, P. K. (2010). Microeconometrics using Stata Revised Edition. Stata Press. https://doi.org/10.1016/S0304-4076(00)00050-6

Castillo-Giménez, J., Montañés, A., \& Picazo-Tadeo, A. J. (2019). Performance and convergence in municipal waste treatment in the European Union. Waste Management. https://doi.org/10.1016/j.wasman.2018.12.025

Conrad, K. (1999). Resource and waste taxation in the theory of the firm with recycling activities. Environmental and Resource Economics. https://doi.org/10.1023/A:1008301626219

Crociata, A., Agovino, M., \& Sacco, P. L. (2015). Recycling waste: Does culture matter? Journal of Behavioral and Experimental Economics . https://doi.org/10.1016/j.socec.2015.01.005

Dijkgraaf, E., \& Gradus, R. (2017). An EU recycling target: What does the Dutch evidence tell us? Environmental and Resource Economics. https://doi.org/10.1007/s10640-016-0027-1

Eurostat. (2013). Manual on Waste Statistics: A Handbook for Data Collection on Waste Generation and Treatment. Theme: Environment and Energy Collection, Methodologies \& Working Papers. https://doi.org/10.2785/51516

Goddard, H. C. (1995). The benefits and costs of alternative solid waste management policies. Resources, Conservation and Recycling. https://doi.org/10.1016/0921-3449(94)00021-V

Henriksson, G., Åkesson, L., \& Ewert, S. (2010). Uncertainty regarding waste handling in everyday life. Sustainability. https://doi.org/10.3390/su2092799

Highfill, J., \& McAsey, M. (2001). Landfilling versus "backstop" recycling when income is growing. Environmental and Resource Economics. https://doi.org/10.1023/A:1011158511648

Huhtala, A. (1999). How much do money, inconvenience and pollution matter? Analysing households' demand for large-scale recycling and incineration. Journal of Environmental Management. https://doi.org/10.1006/jema.1998.0245

Huhtala, Anni. (1997). A post-consumer waste management model for determining optimal levels of recycling and landfilling. Environmental and Resource Economics. https://doi.org/10.1023/A:1026475208718

Ichinose, D., Yamamoto, M., \& Yoshida, Y. (2011). Reexamining the waste-income relationship. GRIPS National Graduate Institute for Policy Studies. Discussion Paper, 10.

Johansson, P. O., \& Kriström, B. (2007). On a clear day you might see an environmental Kuznets curve. Environmental and Resource Economics. https://doi.org/10.1007/s10640007-9112-9 
Johnstone, N., \& Labonne, J. (2004). Generation of household solid waste in OECD countries: An empirical analysis using macroeconomic data. Land Economics, 80(4), 529. https://doi.org/10.2307/3655808

Karousakis, K. (2009). MSW generation disposal and recycling: Empirical evidence from OECD countries. In M. Mazzanti \& A. Montini (Eds.), Waste and Environmental Policy. London: Routledge Explorations in Environmental Economics.

Kinnaman, T. C. (2009). The economics of municipal solid waste management. Waste Management. https://doi.org/10.1016/j.wasman.2009.06.031

Kirakozian, A. (2016). The determinants of household recycling: social influence, public policies and environmental preferences. Applied Economics. https://doi.org/10.1080/00036846.2015.1102843

Lansink, A. (2018). Challenging changes - Connecting waste hierarchy and circular economy. Waste Management and Research. https://doi.org/10.1177/0734242X18795600

Lokrantz, E. (2019). Introducing a New Waste Hierarchy Tax in Sweden: A General Equilibrium Analysis. Lund University. Retrieved from http://lup.lub.lu.se/studentpapers/record/8980756

Marin, G., Nicolli, F., \& Zoboli, R. (2018). Catching-up in waste management. Evidence from the EU. Journal of Environmental Planning and Management. https://doi.org/10.1080/09640568.2017.1333952

Mazzanti, M., Montini, A., \& Nicolli, F. (2009a). The dynamics of landfill diversion: Economic drivers, policy factors and spatial issues Evidence from Italy using provincial panel data. Resources, Conservation and Recycling. https://doi.org/10.1016/j.resconrec.2009.06.007

Mazzanti, M., Montini, A., \& Nicolli, F. (2009b). Waste Kuznets Curves, regional policies and spatial effects Evidence on waste generation and landfill diversion from Italy. https://doi.org/10.2139/ssrn.1593503

Mazzanti, M., \& Zoboli, R. (2008). Waste generation, waste disposal and policy effectiveness. Evidence on decoupling from the European Union. Resources, Conservation and Recycling. https://doi.org/10.1016/j.resconrec.2008.07.003

Nguyen, M., \& Nguyen, H. (2010). Stata Module: Estimates of System of Regression Equations with Unbalanced Panel Data and Random Effects. Working Paper.

Nicolli, F., Mazzanti, M., \& lafolla, V. (2012). Waste dynamics, country heterogeneity and European environmental policy effectiveness. Journal of Environmental Policy and Planning. https://doi.org/10.1080/1523908X.2012.719694

Olsson, L., Wetterlund, E., \& Söderström, M. (2015). Assessing the climate impact of district heating systems with combined heat and power production and industrial excess heat. Resources, Conservation and Recycling. https://doi.org/10.1016/j.resconrec.2015.01.006

Pearce, D. W., \& Turner, R. K. (1993). Market-based approaches to solid waste management. Resources, Conservation and Recycling. https://doi.org/10.1016/0921-3449(93)90020-G

Petersen, T. (2012). Analyzing panel data: Fixed- and random-effects models. In M. Hardy \& A. Bryman (Eds.), Handbook of Data Analysis. London: Sage. https://doi.org/10.4135/9781848608184.n14

Pires, A., \& Martinho, G. (2019). Waste hierarchy index for circular economy in waste management. Waste Management, 95, 298-305.

Rasmussen, C., Vigs $\varnothing$, D., Ackerman, F., Porter, R., Pearce, D., \& Dijkgraaf, E. (2005). Rethinking the waste hierarchy. Rethinking the Waste Hierarchy, 1-21.

Sauter, C. (2014). How Should We Measure Environmental Policy Stringency? A New Approach. IRENE Working Paper.

WEF. (2018). Global Competitiveness Reports 2007-2018. The Global Competitiveness Index 4.0 (Version 13 October, 2018). Switzerland: World Economic Forum.

Werner, S. (2017). District heating and cooling in Sweden. Energy. https://doi.org/10.1016/j.energy.2017.03.052 